\title{
Design and synthesis of thiourea compounds that inhibit transmembrane anchored carbonic anhydrases
}

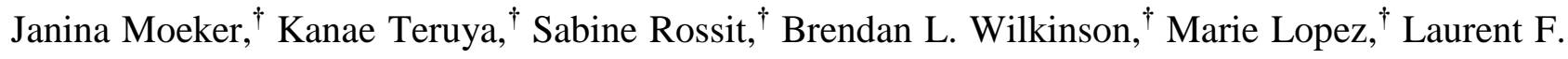
Bornaghi, ${ }^{\dagger}$ Alessio Innocenti, $§$ Claudiu T. Supuran ${ }^{*} \S$ and Sally-Ann Poulsen*, ${ }^{*}$

Eskitis Institute for Cell and Molecular Therapies, Griffith University, 170 Kessels Road, Nathan, Queensland 4111, Australia and Polo Scientifico, Laboratorio di Chimica Bioinorganica, Rm. 188, Università degli Studi di Firenze, Via della Lastruccia 3, 50019 Sesto Fiorentino, Florence, Italy

${ }^{*}$ Corresponding authors. S.-A.P. Telephone: +61 73735 7825; Fax: +61 73735 6001; e-mail: s.poulsen@griffith.edu.au. C.T.S. Telephone: +39 055457 3005; Fax: +39 055457 3385; e-mail: claudiu.supuran@unifi.it.

${ }^{\dagger}$ Griffith University

$\S$ Università degli Studi di Firenze

$¥$ Nonstandard abbreviations: CA, carbonic anhydrase; AZA, acetazolamide; DIPEA, $N, N$ diisopropylethylamine; HSQC, heteronuclear single quantum coherence; HRMS, high resolution mass spectrometry

Keywords: carbonic anhydrase, thiourea, carbohydrate, inhibitor, hypoxia 


\begin{abstract}
A library of 32 novel glycoconjugate thiourea-bridged benzene sulfonamides have been synthesized from the reaction of glycosyl isothiocyanates with a panel of simple benzene sulfonamides comprising either a free amine or hydrazide. All compounds were investigated for their ability to inhibit the enzymatic activity of five human carbonic anhydrase (hCA) isozymes: hCA I, II and membrane-associated isozymes IX, XII and XIV. A physicochemical feature of the free sugar thioureido glycoconjugates was high water solubility $(>20 \mathrm{mg} / \mathrm{mL})$, as well many of these compounds exhibited a desirable potency and CA isozyme selectivity profile. From this library several inhibitors displayed excellent potency-selectivity profiles for transmembrane anchored CAs over off-target CA I and II. These molecules provide potential dual-acting candidates for the development of inhibitors that target the extracellular CAs (IX, XII and XIV) - either directly as free sugars (membrane impermeable) or indirectly as acetylated prodrugs, becoming free sugars upon esterase hydrolysis.
\end{abstract}




\section{Introduction}

Carbonic anhydrases (CA, EC 4.2.1.1) are zinc metalloenzymes that catalyze the reversible hydration of carbon dioxide $\left(\mathrm{CO}_{2}\right)$ to bicarbonate $\left(\mathrm{HCO}_{3}{ }^{-}\right)$and a proton $\left(\mathrm{H}^{+}\right)$, Scheme 1. ${ }^{1}$ This physiological equilibrium underpins $\mathrm{pH}$ homeostasis, ion transport and fluid secretion. There are 12 catalytically active isoforms of CA characterized in humans; five isozymes are cytosolic (CA I, II, III, VII and XIII), two are found in mitochondria (CA VA and VB), one is secreted (CA VI) and four are transmembrane anchored with an extracellular facing active site (CA IV, IX, XII and XIV). These isozymes differ in tissue distribution, catalytic activity and expression profiles, a situation that allows medicinal chemists an opportunity to develop strategies for the selective targeting of CA isozymes of interest with small molecules. CA inhibitors have now been a mainstay of human clinical intervention for several decades, with at least 25 clinically used drugs known that are CA inhibitors. ${ }^{2}$ Despite this longevity, the CA enzyme family continues to capture the attention of drug discovery scientists and clinicians as the knowledge regarding the therapeutic implications associated with this enzyme class continues to grow. ${ }^{2,3}$

Scheme 1. Catalytically active CA enzymes catalyze the reversible hydration of carbon dioxide to give bicarbonate and a proton.

$$
\mathrm{CO}_{2}+\mathrm{H}_{2} \mathrm{O} \leftrightarrows \mathrm{HCO}_{3}^{-}+\mathrm{H}^{+}
$$

The role of transmembrane CA IX and XII enzymes was recently shown to be essential for sustaining $\mathrm{pH}$ regulation in hypoxic tumor cells and to support an environment suited for tumor cell survival and proliferation. The low oxygen environment of hypoxic tumors brings about a shift from aerobic to anaerobic glucose metabolism, this in turn leads to the production of excess lactic acid and $\mathrm{CO}_{2}$ in the tumor cell. Maintenance of the delicate balance of intracellular and extracellular $\mathrm{pH}$, which if unchecked would interfere with the tumor cells viability, requires the interplay of a number of sophisticated pathways. The expression of CA IX and XII is upregulated in many hypoxic tumors, however CA IX is usually absent in the corresponding normal tissue, while CA XII is expressed in a selection of normal tissues. ${ }^{4,5}$ The disruption of CA IX and/or XII-mediated $\mathrm{pH}$ homeostasis has been shown to generate a cancer-cell selective cytotoxic environment. $^{6,7}$ Significantly, this constitutes a new mechanism of action that may be targeted in the context of developing next generation cancer therapeutics. ${ }^{8}$ G250 is a monoclonal antibody that first underwent clinical trials in $1993,{ }^{9}$ long before its antigen was identified as CA IX in $2000 .{ }^{10} \mathrm{CA}$ IXspecific monoclonal antibodies are presently in Phase III clinical development as both therapeutic and diagnostic agents. ${ }^{8}$ The results from targeting CA IX with antibodies have advanced our 
understanding of the pivotal role of CAs in cancer, underpinning the impetus to assess the therapeutic potential of CA IX and XII inhibition using small molecules. CA-relevant animal models of tumors are only recently available, and as a result the first small molecule CA inhibitors have commenced preclinical development. ${ }^{8}$ Transmembrane CA XIV expression is abundant in eye, brain, kidney, colon, small intestine, urinary bladder, liver, and spinal cord where it has a role in buffering to regulate acid-base balance, CA XIV is not associated with tumors. ${ }^{11,12}$ The therapeutic implications of inhibition (or activation) of CA XIV are less well described than for CA IX and XII, and relatively few studies have identified inhibitors of this isozyme or attempted to address selectivity for/against this isozyme. ${ }^{13-15}$ The ensuing drug discovery pipeline challenges that lay ahead for anticancer CA inhibitors imply that drug-like small molecules that selectively target CA IX and XII over off-target CAs will be required to address the growing interest in the potential clinical applications of this enzyme class in oncology. ${ }^{3}$ The same rationale applies to CA XIV inhibitors, for which there are presently few potent inhibitors and no selective inhibitors.

The classical small molecule CA inhibitors are primary aryl sulfonamide compounds (R$\mathrm{SO}_{2} \mathrm{NH}_{2}$ ), the sulfonamide anion $\left(\mathrm{R}-\mathrm{SO}_{2} \mathrm{NH}^{-}\right.$) coordinates to the $\mathrm{CA}$ active site $\mathrm{Zn}^{2+}$ and blocks the endogenous substrates from binding. ${ }^{1,2} \mathrm{CAs}$ are a challenging drug target for developing isozyme selective inhibitors as the active site of different isozymes is structurally similar. However CA IX and XII hold distinguishing features that provide an opportunity for selective inhibition by tuning the physicochemical properties of small molecule inhibitors. First, hypoxic tumors overexpress CA IX and XII while many healthy tissues lack these isozymes. ${ }^{4}{ }^{5}$ Second, CA IX and XII have an extracellular enzyme active site. The properties of small molecules may be modified to take advantage of the cell lipid membrane as a barrier that separates target (extracellular) from off-target (cytosolic) CAs, and CA inhibitors with poor membrane permeability may selectively target CA IX and XII over intracellular CAs. The 'tail' approach for CA inhibitor development involves adding tail groups to the $\mathrm{R}-\mathrm{SO}_{2} \mathrm{NH}_{2}$ scaffold to enhance physicochemical properties of the inhibitor whilst assisting isozyme selectivity. ${ }^{16}$ Using this approach CA inhibitors that incorporate a hydrophilic moiety have been developed with limited membrane permeability. ${ }^{16-23}$ Such compounds are useful as tools to study the role of CA in cancer biology. Primary sulfonamides that incorporate a thiourea linker between the aromatic benzene sulfonamide moiety and the tail moiety have shown excellent inhibition of a selection of CA isozymes, and this class of inhibitors has been developed as CA IXselective imaging agents. ${ }^{24-35}$ In this paper we combine these two aforementioned strategies to synthesize carbohydrate-based (hydrophilic tail moiety), thiourea-bridged (robust linker to tail) 
glycoconjugate CA inhibitors and develop potent and selective inhibitors of the transmembrane CAs.

\section{Results and Discussion}

2.1. Chemistry. The thiourea link is most commonly synthesized from the reaction of an isothiocyanate with a primary amine, thus for the synthesis of target thiourea-bridged glycoconjugate CA inhibitors two possible synthetic strategies are conceivable, one where the isothiocyanate partner comprises the primary sulfonamide and one where the isothiocyanate partner comprises the carbohydrate. Thiourea-linked CA inhibitors have been synthesized by others and in all examples the isothiocyanate reacting partner comprises the sulfonamide, with the isothiocyanate functional group introduced using the highly toxic reagent thiophosgene $\left(\mathrm{CSCl}_{2}\right) \cdot{ }^{24-35}$ In this study we employ the 'reverse polarity' approach; the advantage of this being two-fold: (i) glycosyl isothiocyanates are readily synthesized from inexpensive per- $O$-acetylated sugars using convenient reagents in comparison to thiophosgene, and (ii) as numerous benzene sulfonamide compounds possessing also a primary amine functional group are commercially available, these compounds require no synthetic manipulation prior to use. To the best of our knowledge this is the first time the reverse polarity synthetic strategy has been used to prepare thiourea-bridged CA inhibitors. The amino sulfonamide compounds (1-3), as well as 4-hydrazidobenzene sulfonamide (4), a compound

we had previously synthesized, ${ }^{36,37}$ were included as amino building blocks in this study, Chart 1 . Hydrazide 4 allows access to an extended thiourea-based bridging group. Four per- $O$-acetylated glycosyl isothiocyanates, derived from (5) D-glucose, (6) D-galactose, (7) maltose and (8) lactose respectively, were also included, Chart 1 . The four isothiocyanate carbohydrate building blocks, together with the selection of four amino sulfonamide reaction partners provided a straightforward avenue to molecular diversity. With free and peracetylated sugars a subsequent 32-member thiourea-bridged glycoconjugate CA inhibitor library has been synthesized to investigate CA inhibition and to interrogate the CA active site architecture, Chart 2. These thiourea-bridged glycoconjugates provide complex structures with significant variation in hydrogen bonding propensity, steric bulk and hydrophobic character. 
Chart 1. Amino (1-4) and isothiocyanate (5-8) building blocks used for the synthesis of target thiourea-bridged glycoconjugate CA inhibitors. [to be reproduced in color on the Web and in blackand-white in print]

TARGET CA INHIBITORS
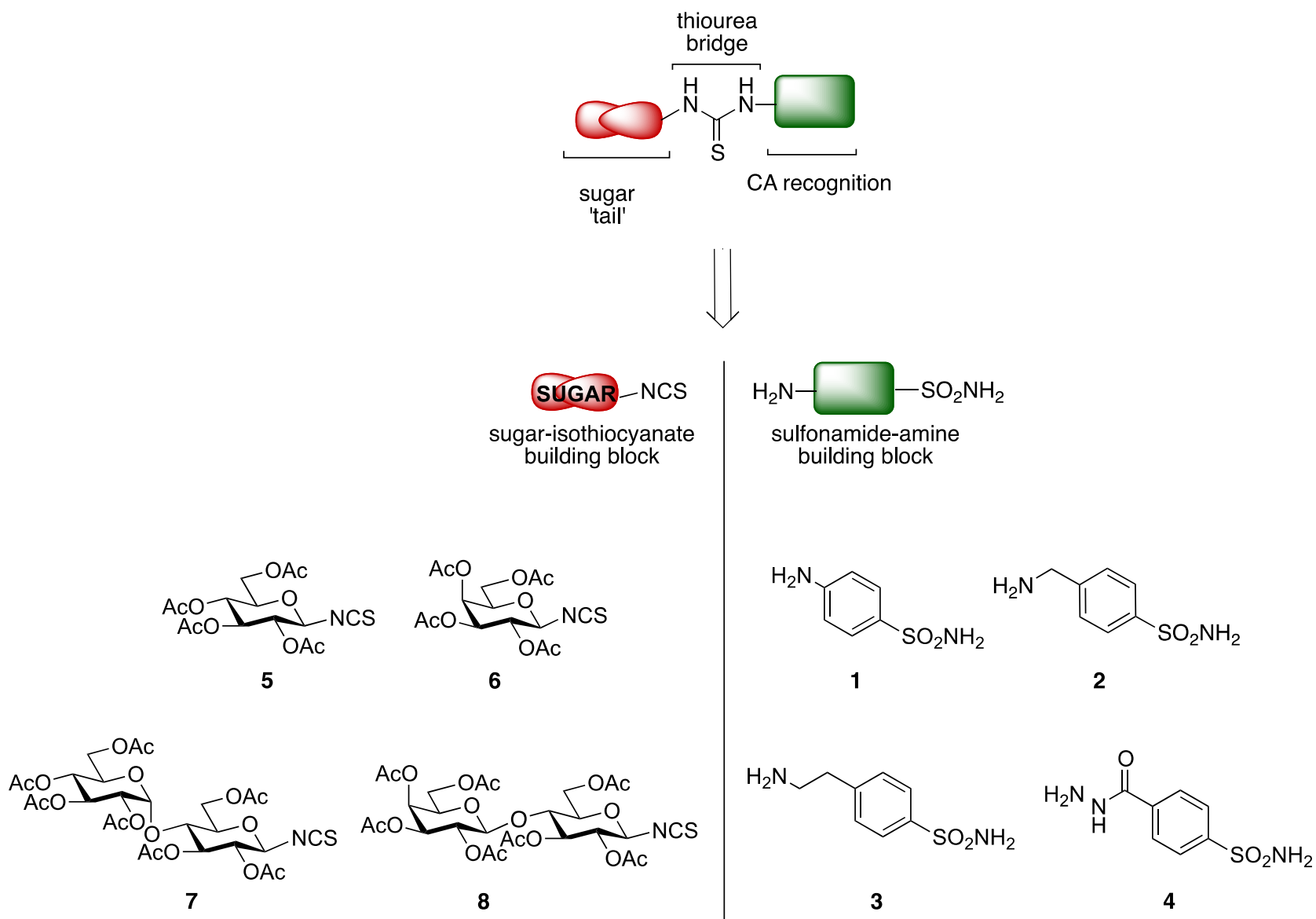
Chart 2. 32-Member thiourea-bridged glycoconjugate CA inhibitor library 9-40.

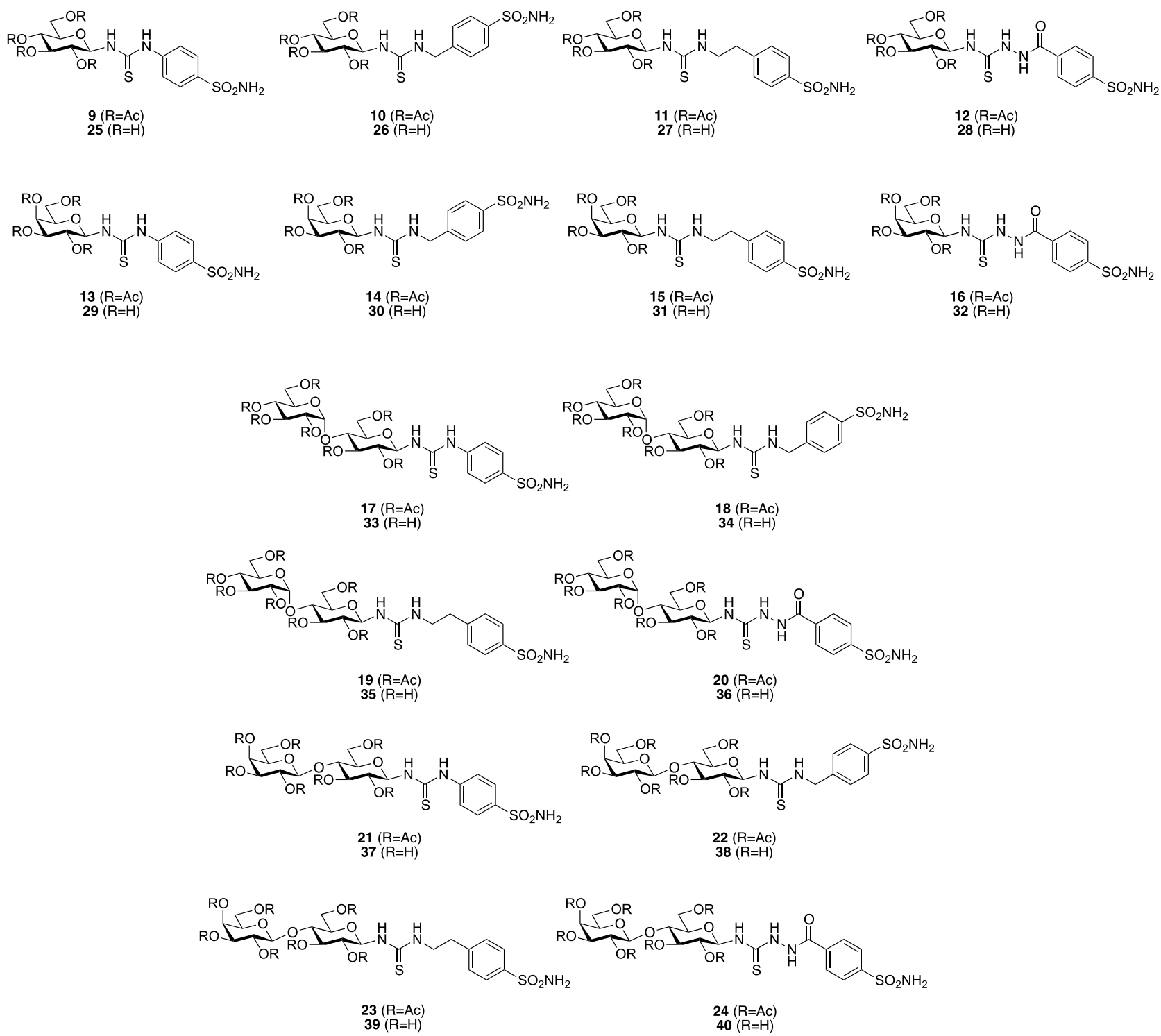

Glycosyl isothiocyanates 5-8 were synthesized from per- $O$-acetylated sugars, either indirectly from reaction of a glycosyl bromide intermediate (made from the per- $O$-acetylated sugar in $\mathrm{HBr}$-acetic acid) with excess $\mathrm{KSCN}^{38}{ }^{3}$ or directly with trimethylsilyl isothiocyanate (TMS-SCN) under Lewis acid catalysis in dichloromethane (a mild one-step procedure), ${ }^{39}$ Scheme 1 . The latter method was preferred as it avoided the complication of generating and then separating a mixture of target glycosyl isothiocyanate and unwanted glycosyl thiocyanates. Per- $O$-acetylated maltose and lactose starting materials were prepared from the free sugar precursor using the standard $O$ acetylation reaction conditions with acetic anhydride and sodium acetate. The target thioureabridged compounds 9-24 were synthesized by the reaction of glycosyl isothiocyanate building blocks 5-8 with an equimolar amount of amine partner 1-4 in acetonitrile at $40{ }^{\circ} \mathrm{C}$, Scheme 1. Sulfonamides $\mathbf{1}$ and $\mathbf{4}$ were less reactive than sulfonamides $\mathbf{2}$ and $\mathbf{3}$ so excess $\mathbf{1}$ and $\mathbf{4}$ was utilized to 
improve the product yields. Reactions proceeded with the retention of the stereochemistry at the anomeric centre. Deacetylation of the sugar moieties of compounds 9-24 was achieved using 0.1 M sodium methoxide in methanol ${ }^{40}$ affording deprotected compounds 25-40 in good yield. A physicochemical feature of the free sugar thioureido glycoconjugates was high water solubility $(>$ $20 \mathrm{mg} / \mathrm{mL})$.

Scheme 1. Synthesis of target thiourea-bridged glycoconjugate CA inhibitor compounds 9-40.

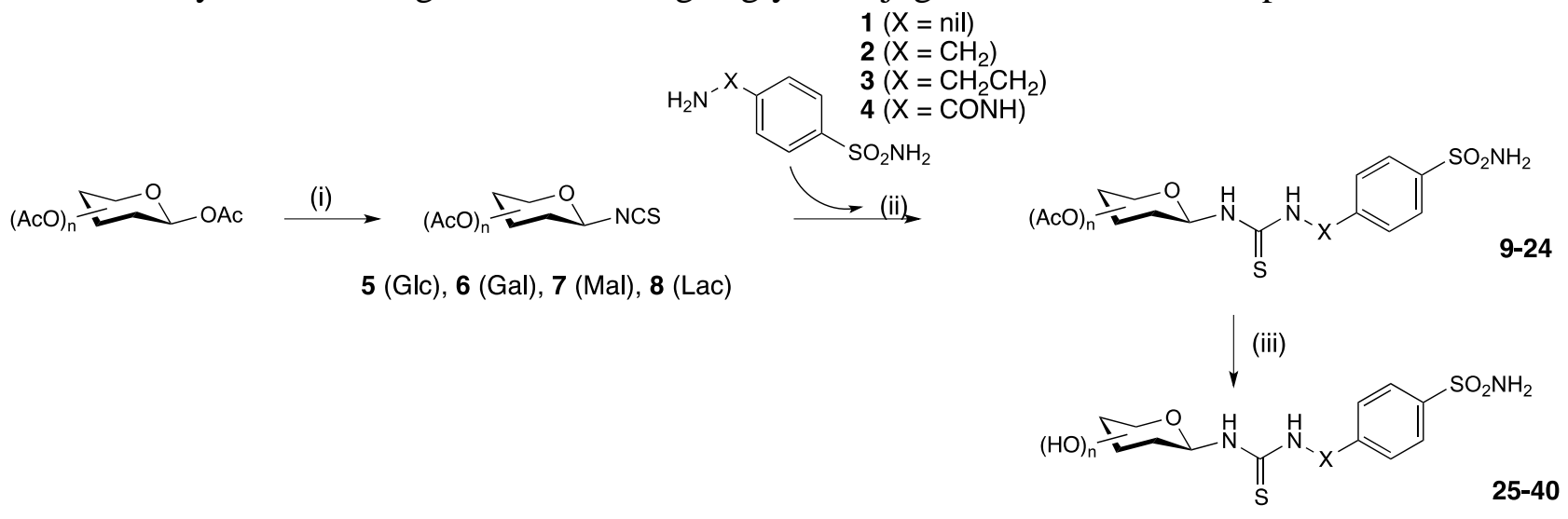

Reagents and Conditions: (i) per- $O$-acetylated sugar (1.0 equiv), $\mathrm{SnCl}_{4}$ (0.1 equiv), TMS-SCN (1.1 equiv), anhydrous $\mathrm{CH}_{2} \mathrm{Cl}_{2}, 30{ }^{\circ} \mathrm{C}, 16 \mathrm{~h}$; ii) $\mathbf{1 - 4}$ (1.0 equiv for $\mathbf{2}$ and $\mathbf{3}, 2$ equiv for $\mathbf{1}$ and 4), 5-8 (1.0 equiv), anhydrous $\mathrm{CH}_{3} \mathrm{CN}, 40{ }^{\circ} \mathrm{C}, 2 \mathrm{~h}-2$ days (64-98\%). c) $\mathrm{NaOMe}$ in $\mathrm{MeOH}$ (25\% w/v, pH 912), anhydrous $\mathrm{MeOH}, \mathrm{rt}, 30 \mathrm{~min}-2 \mathrm{~h}(86-95 \%)$.

2.2. Carbonic Anhydrase Inhibition Studies. The enzyme inhibition data for 9-40 as well as clinically used par excellence CA inhibitor acetazolamide (AZA) were obtained for the physiologically dominant CA I and II, tumor-associated transmembrane CA IX and XII, and transmembrane CA XIV, Table 1. Selected inhibition data for parent sulfonamide CA inhibitors 1-4 are also provided. Table 2 shows the selectivity data for the thiourea library compounds at transmembrane CAs (IX, XII and XIV) over off-target CAs (I and II), the $K_{\mathrm{i}}$ ratios are indicative of isozyme selectivity for transmembrane CAs. 
Table 1. CA inhibition data for thiourea-bridged compounds 9-40, parent sulfonamides 1-4 and the clinically used CA inhibitor AZA against human CA isozymes I, II, IX, XII and XIV.

\begin{tabular}{|c|c|c|c|c|c|}
\hline \multirow{2}{*}{ Compd. } & \multicolumn{5}{|c|}{$K_{\mathrm{i}} \mathrm{s}(\mathrm{nM})^{a}$} \\
\hline & $\mathbf{I}^{b}$ & $\mathbf{I I}^{b}$ & $\mathbf{I X}^{c}$ & $\mathbf{X I I}^{c}$ & $\mathbf{X I V}^{d}$ \\
\hline AZA & 250 & 12 & 25 & 5.7 & 41 \\
\hline 9 & 4930 & 7.0 & 6.9 & 7.2 & 8.3 \\
\hline 10 & 100 & 7.8 & 7.4 & 7.5 & 8.5 \\
\hline 11 & 5510 & 7.3 & 451 & 8.9 & 8.8 \\
\hline 12 & 3770 & 10 & 8.7 & 7.3 & 10.3 \\
\hline 13 & 6710 & 524 & 7.3 & 45.6 & 126 \\
\hline 14 & 6340 & 11.9 & 5.8 & 100 & 807 \\
\hline 15 & 100 & 297 & 433 & 8.8 & 8.7 \\
\hline 16 & 6410 & 8.6 & 3.3 & 7.8 & 10.7 \\
\hline 17 & 6040 & 539 & 7.4 & 10.1 & 7.9 \\
\hline 18 & 4570 & 7.3 & 7.5 & 8.4 & 8.6 \\
\hline 19 & 3720 & 9.8 & 122 & 8.4 & 8.7 \\
\hline 20 & 2940 & 10.2 & 9.1 & 7.6 & 10.5 \\
\hline 21 & 100 & 7.6 & 7.5 & 8.2 & 8.6 \\
\hline 22 & 110 & 390 & 7.3 & 7.4 & 8.5 \\
\hline 23 & 3770 & 8.7 & 362 & 48.1 & 9.1 \\
\hline 24 & 5900 & 6.4 & 8.9 & 8.1 & 10.6 \\
\hline 25 & 7680 & 7.0 & 282 & 8.2 & 41 \\
\hline 26 & 7500 & 377 & 8.8 & 8.2 & 16.0 \\
\hline 27 & 9.0 & 108 & 8.7 & 9.7 & 8.0 \\
\hline 28 & 7880 & 525 & 112 & 8.6 & 8.0 \\
\hline 29 & 6840 & 222 & 7.0 & 20.1 & 125 \\
\hline 30 & 6420 & 60.0 & 6.9 & 111 & 129 \\
\hline 31 & 5790 & 9.3 & 2.8 & 10.2 & 108 \\
\hline 32 & 4040 & 344 & 121 & 8.5 & 8.2 \\
\hline 33 & 7920 & 7.5 & 8.4 & 300 & 9.8 \\
\hline 34 & 6300 & 376 & 8.4 & 12.5 & 8.5 \\
\hline 35 & 4260 & 271 & 2.1 & 9.8 & 7.8 \\
\hline
\end{tabular}




$\begin{array}{lccccc}\mathbf{3 6} & 4780 & 109 & 115 & 8.2 & 8.6 \\ \mathbf{3 7} & 7980 & 6.9 & 258 & 81 & 55 \\ \mathbf{3 8} & 4060 & 105 & 8.3 & 7.9 & 44 \\ \mathbf{3 9} & 100 & 9.0 & 8.9 & 13.5 & 8.4 \\ \mathbf{4 0} & 110 & 7.4 & 113 & 8.7 & 8.5 \\ \mathbf{1} & 5000 & 240 & 294 & 37 & 5400 \\ \mathbf{2} & 25000 & 170 & 103 & 0.3 & 3200 \\ \mathbf{3} & 21000 & 160 & 33 & 3.2 & 2900 \\ \mathbf{4} & 2950 & 124 & 175 & - & -\end{array}$

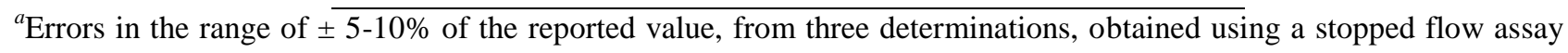
that monitors the physiological reaction $\left(\mathrm{CA}\right.$ catalysed hydration of $\left.\mathrm{CO}_{2}\right) .{ }^{b}$ Human (cloned) isozymes. ${ }^{c}$ Catalytic domain of human (cloned) isozymes. ${ }^{41,42 d}$ Full-length human (cloned) isozymes. ${ }^{14}$

Table 2. CA isozyme selectivity data for thiourea-bridged compounds 9-40.

\begin{tabular}{|c|c|c|c|c|c|c|}
\hline \multirow{2}{*}{ Compd. } & \multicolumn{6}{|c|}{ Selectivity $\left(K_{\mathrm{i}}\right)$ ratios $^{a}$} \\
\hline & I/IX & I/XII & I/XIV & II/IX & II/XII & II/XIV \\
\hline 9 & 714 & 685 & 594 & $\sim 1$ & $\sim 1$ & $\sim 1$ \\
\hline 10 & 14.1 & 13.3 & 11.8 & $\sim 1$ & $\sim 1$ & $\sim 1$ \\
\hline 11 & 12.2 & 619 & 626 & 0.02 & $\sim 1$ & $\sim 1$ \\
\hline 12 & 433 & 516 & 366 & $\sim 1$ & $\sim 1$ & $\sim 1$ \\
\hline 13 & 919 & 147 & 53.3 & 71.8 & 11.5 & 4.2 \\
\hline 14 & 1093 & 63.4 & 7.9 & 2.1 & 0.12 & 0.002 \\
\hline 15 & 0.23 & 11.4 & 11.5 & 0.69 & 33.8 & 34.1 \\
\hline 16 & 1942 & 822 & 599 & 2.6 & $\sim 1$ & $\sim 1$ \\
\hline 17 & 816 & 598 & 765 & 72.8 & 53.4 & 68.2 \\
\hline 18 & 609 & 544 & 531 & $\sim 1$ & $\sim 1$ & $\sim 1$ \\
\hline 19 & 30.5 & 443 & 428 & 0.08 & $\sim 1$ & $\sim 1$ \\
\hline 20 & 323 & 387 & 280 & $\sim 1$ & $\sim 1$ & $\sim 1$ \\
\hline 21 & 13.3 & 12.2 & 11.6 & $\sim 1$ & $\sim 1$ & $\sim 1$ \\
\hline 22 & 15.1 & 14.9 & 12.9 & 53.4 & 52.7 & 45.9 \\
\hline 23 & 10.4 & 78.4 & 414 & 0.02 & 0.18 & $\sim 1$ \\
\hline 24 & 663 & 729 & 557 & $\sim 1$ & $\sim 1$ & $\sim 1$ \\
\hline 25 & 27.2 & 937 & 187 & 0.02 & $\sim 1$ & 0.17 \\
\hline 26 & 852 & 915 & 469 & 42.8 & 46.0 & 23.6 \\
\hline 27 & $\sim 1$ & $\sim 1$ & $\sim 1$ & 12.4 & 11.1 & 13.5 \\
\hline
\end{tabular}




$\begin{array}{lcccccc}\mathbf{2 8} & 70.4 & 916 & 985 & 4.7 & 61.0 & 65.6 \\ \mathbf{2 9} & 977 & 340 & 54.7 & 31.7 & 11.0 & 1.8 \\ \mathbf{3 0} & 930 & 57.8 & 49.8 & 8.7 & 0.5 & 0.5 \\ \mathbf{3 1} & 2068 & 568 & 53.6 & 3.3 & \sim 1 & 0.09 \\ \mathbf{3 2} & 11.7 & 475 & 493 & 2.8 & 40.5 & 42.0 \\ \mathbf{3 3} & 943 & 26.4 & 808 & \sim 1 & 0.03 & \sim 1 \\ \mathbf{3 4} & 750 & 504 & 741 & 44.8 & 30.1 & 44.2 \\ \mathbf{3 5} & 2029 & 435 & 546 & 129 & 27.7 & 34.8 \\ \mathbf{3 6} & 41.6 & 583 & 556 & \sim 1 & 13.3 & 12.7 \\ \mathbf{3 7} & 30.9 & 98.5 & 145 & 0.03 & 0.09 & 0.13 \\ \mathbf{3 8} & 489 & 514 & 92.2 & 12.7 & 13.3 & 2.4 \\ \mathbf{3 9} & 11.2 & 7.4 & 11.9 & \sim 1 & \sim 1 & \sim 1 \\ \mathbf{4 0} & \sim 1 & 12.6 & 12.9 & 0.07 & \sim 1 & \sim 1\end{array}$

${ }^{a}$ The $K_{\mathrm{i}}$ ratios are indicative of isozyme selectivity for transmembrane CAs IX, XII and XIV.

2.2.1. Off-target isozymes CA I and II. The parent sulfonamide building blocks 1-4 were weak or very weak inhibitors of CA I $\left(K_{\mathrm{i}} \mathrm{s} 2950-25000 \mathrm{nM}\right)$. At CA I the thiourea glycoconjugates were generally weaker CA inhibitors ( 1000-fold weaker) than for other CA isozymes, with predominantly micromolar inhibition constants. These values are consistent with studies with unrelated benzene sulfonamide class of compound where CA I inhibition is often weaker than for other CA isozymes. ${ }^{2}$ The only outlier to this general trend was the D-glucose derived thiourea 27 which showed very good CA I inhibition $\left(K_{\mathrm{i}} 9.0 \mathrm{nM}\right)$. At CA II the parent sulfonamides $\mathbf{1 - 4}$ had $K_{\mathrm{i}} \mathrm{s}$ in the range of $124-240 \mathrm{nM}$, much more potent than at CA I. For the acetyl protected sugar series 9-24 CA II $K_{\mathrm{i}}$ s ranged from $6.4-539 \mathrm{nM}$, with two distinct groupings: potent inhibitors 9-12, 14, 16, 18-21, 23-34 $\left(K_{\mathrm{i}} \leq 10 \mathrm{nM}\right)$ and weaker inhibitors 13, 15, 17 and $22\left(K_{\mathrm{i}}\right.$ 297-539 nM). The weaker CA II inhibitors were derived from a combination of parent sulfonamides $\mathbf{1}, \mathbf{2}$ and $\mathbf{3}$ with parent sugars $6 \mathrm{Gal}, 7 \mathrm{Mal}$ and $8 \mathrm{Lac}$ - this widespread origin of pharmacophore components demonstrate that SAR is not straightforward. With the deprotected sugars $\mathbf{2 5 - 4 0}$ there were also two distinct inhibition classes with six potent inhibitors $\left(K_{\mathrm{i}} \leq 10 \mathrm{nM}\right)$ and ten weaker inhibitors $\left(K_{\mathrm{i}} 60\right.$ $525 \mathrm{nM}$ ) and again there pharmacophore components are widespread. Overall the acylated compounds were typically better CA II inhibitors than the free sugars, indicating that the bulkier $O$ acetate compounds are well tolerated at CA II. The only exceptions are compounds 15 and 17, where the free sugar analogues (31 and 33, respectively) were more potent than the acylated counterpart. 
2.2.2. Cancer-associated isozymes CA IX and XII. At CA IX the parent sulfonamides $\mathbf{1 - 4}$ had $K_{\mathrm{i}} \mathrm{S}$ in the range of $33-294 \mathrm{nM}$, while at CA XII inhibition was 0.3 - $37 \mathrm{nM}$. Many thiourea compounds exhibited potent inhibition of CA IX with $K_{\mathrm{i}} \mathrm{s}<10 \mathrm{nM}$. There were also several potent CA IX inhibitors that had notable selectivity for CA IX compared to the off-target isozymes I and II (compounds 13, 17, 26, 29, 34 and 35); most impressive was the maltose-based compound 35 with a CA IX $K_{\mathrm{i}}$ of $2.1 \mathrm{nM}$ (2029-fold selectivity over CA I and 129-fold selectivity over CA II); it is the most potent and selective CA IX inhibitor of this study and one of the most potent and selective CA IX inhibitors reported in the literature. ${ }^{2}$ Most acetylated thiourea glycoconjugates exhibited potent inhibition of CA XII, with $K_{\mathrm{i}} \mathrm{s}$ clustered close to $10 \mathrm{nM}$, in addition many of the free sugar thiourea glycoconjugates were also in this category. Just five compounds from the 32-member library had CA XII inhibition above $15 \mathrm{nM}$, while for CA IX there were ten compounds above $15 \mathrm{nM}$, only two compounds were weak inhibitors of both CA IX and XII (compounds 23 and 37) indicating that CA $\mathrm{XII}$ inhibition is slightly favored by the compounds in this library. Glycoconjugates were selective for CA XII over CA I by one to three orders of magnitude, with the exception of one compound (compound 27 was non-selective as it has a low CA I inhibition $K_{\mathrm{i}}$ of $9 \mathrm{nM}$ ). About half of the glycoconjugate compounds were also selective for CA XII over II, notably many of the free sugars (26-29, 32, 34-36, 38) were in this grouping. There were four standout cancer-associated CA selective inhibitors (selective for CA IX and CA XII compared to the off-target CAs), these were the acylated compound 17 (816-fold over CA I and 73-fold over CA II) and the free sugar compounds 26 (852-fold over CA I and 43-fold over CA II), 34 (750-fold over CA I and 45-fold over CA II) and 35 (2029-fold over CA I and 129-fold over CA II). This potency-selectivity profile is a much sought after characteristic for CA inhibitors and represents an important finding for the provision of good lead compounds with anticancer potential for future biological applications as anticancer agents.

2.2.3. Isozyme hCA XIV. There are few benzene sulfonamide compounds for which CA XIV inhibition has been determined, however from these studies it has been shown that this isozyme is more resistant to inhibition than CA IX and XII. ${ }^{13,14}$ The simple parent sulfonamide compounds $\mathbf{1 - 3}$ have CA XIV $K_{\mathrm{i}} \mathrm{s}$ of $2900-5400 \mathrm{nM}$, much less than for the other transmembrane CAs. The thiourea-bridged glycoconjugate sulfonamides of the present study provide complex structures with significant variation in hydrogen bonding propensity, steric bulk and hydrophobic character. While parent sulfonamides 1-3 have weak $K_{\mathrm{i}}$ values, most acetylated compounds have $K_{\mathrm{i}} \mathrm{s}$ of $\leq 10 \mathrm{nM}$ with the only outliers being 13 and 14, with $K_{\mathrm{i}} \mathrm{s}$ of 126 and $807 \mathrm{nM}$, respectively. For the free sugars 
there were also many potent CA XIV inhibitors, outliers include $\mathbf{2 9}$ and $\mathbf{3 0}$ (the same core structure as acetylated 13 and 14) as well as 31, 37 and 38. Interestingly, 13, 14, 29-31 are all galactosebased compounds, which may indicate that this isozyme is more responsive to subtle variations in stereochemistry compared to other CAs. With regard to selectivity for CA XIV over off-target isozymes, most compounds had good selectivity compared to CA I, with a selection of these compounds (17, 26, 28, 32, 34 and 35) also exhibiting good selectivity (23- to 68-fold) over CA II. As for cancer-associated CAs, this potency-selectivity profile is necessary for the provision of good lead compounds to assess the biological implications of CA XIV inhibition.

2.3 Compound Solubility. Poor drug solubility may lead to poor absorption and bioavailability following oral dosing, hence solubility is an important physicochemical property in drug discovery. ${ }^{43}$ The free sugar thioureido glycoconjugates 25-40 exhibited very good water solubility ( $>20 \mathrm{mg} / \mathrm{mL}$ ). Log $\mathrm{P}$ represents intrinsic lipophilicity and compounds with $\log \mathrm{P}<0$ typically have good solubility. ${ }^{43}$ The calculated $\log \mathrm{P}$ (cLog $\left.\mathrm{P}\right)$ values for the thiourea bridged glycoconjugate CA inhibitors 9-40 are presented in Table 3. The cLog P values for free sugars 2540 are consistent with this good solubility, the cLog Ps for monosaccharides 25-32 (four free hydroxyl groups) range from -1.51 to -2.13 while the cLog Ps for the disaccharides 33-40 (seven free hydroxyl groups) range from -3.70 to -5.06 . The cLog $\mathrm{P}$ values for the acetylated sugars 9-24 range from -0.73 to 1.04 and are consistent with the incorporated acetate groups, decreasing the polarity of the resulting sugar moiety. Although compounds 9-24 are several clog P units less negative than 25-40, the impact of the polar thiourea linkage is evident such that cLog $\mathrm{P}$ are in the reange where these compounds may also have good water solubility. There may be potential to manipulate compound behaviour in vivo by consideration of solubility together with esterase-labile protecting groups in this class of CA inhibitor.

Table 3. The calculated $\log \mathrm{P}(\operatorname{cLg} \mathrm{P})$ values for the thiourea bridged glycoconjugate CA inhibitors 9-40. [to be reproduced in color on the Web and in black-and-white in print]

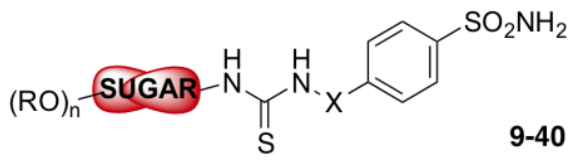

\begin{tabular}{|c|c|c|c|c|c|c|}
\hline Compd. & $\mathbf{X}$ & $(R O)_{n}$ SUGAR & cLogP & Compd. & (RO) SUGAR & cLogP \\
\hline 9 & - & $\underbrace{O A C}_{C_{A c}}$ & 0.01 & 25 & ${ }_{\mathrm{OH}}^{\mathrm{OH}}$ & -2.13 \\
\hline
\end{tabular}




\begin{tabular}{|c|c|c|c|c|c|c|}
\hline 10 & $\mathrm{CH}_{2}$ & ${ }_{A=1}^{O A C}$ & 0.12 & 26 & ${ }_{\mathrm{HO}}^{\mathrm{OH}} \underbrace{\mathrm{O}_{\mathrm{O}}^{\mathrm{O}}}_{\mathrm{OH}}$ & -2.02 \\
\hline 11 & $\mathrm{CH}_{2} \mathrm{CH}_{2}$ & ${ }_{\mathrm{A} A c}^{\mathrm{OcO}}$ & 0.63 & 27 & ${ }_{\mathrm{HO}}^{\mathrm{OH}}$ & -1.51 \\
\hline 12 & NHCO & 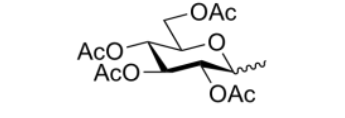 & -0.73 & 28 & ${ }_{\mathrm{HOH}}^{\mathrm{OH}}$ & -2.87 \\
\hline 13 & - & ( & 0.01 & 29 & (NOH & -2.13 \\
\hline 14 & $\mathrm{CH}_{2}$ & ${ }^{A c O} \underbrace{O A C}_{O A C}$ & 0.12 & 30 & & -2.02 \\
\hline 15 & $\mathrm{CH}_{2} \mathrm{CH}_{2}$ & (AcO) & 0.63 & 31 & & -1.51 \\
\hline 16 & NHCO & (AcO) & -0.73 & 32 & & -2.87 \\
\hline 17 & - & ${ }_{A=1}^{\mathrm{OAC}}$ & 0.42 & 33 & $\underbrace{\mathrm{OH}}_{\mathrm{OH}}$ & -4.32 \\
\hline 18 & $\mathrm{CH}_{2}$ & 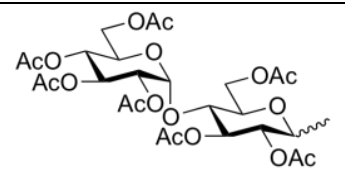 & 0.54 & 34 & $\underbrace{\mathrm{OH}}_{\mathrm{OH}}$ & -4.20 \\
\hline 19 & $\mathrm{CH}_{2} \mathrm{CH}_{2}$ & $\underbrace{\mathrm{OAC}}_{\mathrm{OAC}_{\mathrm{AcO}}}$ & 1.04 & 35 & $\mathrm{HO}^{\mathrm{HO}}$ & -3.70 \\
\hline 20 & NHCO & $\underbrace{\mathrm{OACO}}_{\mathrm{OAC}}$ & -0.32 & 36 & $\underbrace{\mathrm{OH}}_{\mathrm{OH}}$ & -5.06 \\
\hline 21 & - & $\underbrace{A C O}_{O A C} \underbrace{O A C}_{O A C}$ & 0.42 & 37 & $\underbrace{\mathrm{HO}}_{\mathrm{OH}} \mathrm{HO}_{\mathrm{OH}}^{\mathrm{OH}}$ & -4.32 \\
\hline 22 & $\mathrm{CH}_{2}$ & $\underbrace{O A C O}_{O A C} \underbrace{O A c}_{O A C}$ & 0.54 & 38 & $\underbrace{\mathrm{HO}}_{\mathrm{OH}} \underbrace{\mathrm{OH}}_{\mathrm{OH}}$ & -4.20 \\
\hline 23 & $\mathrm{CH}_{2} \mathrm{CH}_{2}$ & 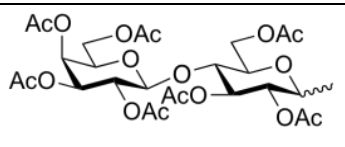 & 1.04 & 39 & $\underbrace{\mathrm{HO}}_{\mathrm{OH}} \underbrace{\mathrm{OH}}_{\mathrm{OH}}$ & -3.70 \\
\hline 24 & NHCO & 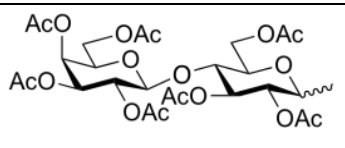 & -0.32 & 40 & $\underbrace{\mathrm{HO}}_{\mathrm{OH}} \underbrace{\mathrm{OH}}_{\mathrm{OH}}$ & -5.06 \\
\hline
\end{tabular}




\section{Conclusions}

A prerequisite for assessing the potential of new CA inhibitor-based therapies is the development of isozyme selective CA inhibitors as research tools. It is desirable to have compounds with potency and specificity in order to avoid effects associated with off-target CA inhibition. This is however a challenging goal as the three-dimensional architecture of the CA catalytic site is strongly conserved across the catalytically active human isozymes. Within this study we have prepared a library of 32 novel thiourea-bridged glycoconjugates as $\mathrm{CA}$ inhibitors. Compounds were evaluated for in vitro inhibition at cytosolic off-target isozymes CA I and II, and for the cancer-related and membraneassociated extracellular CA IX and XII, as well as membrane-associated CA XIV. Therapeutic applications for CA XIV are likely to be discovered as the biology surrounding this isozyme becomes clearer. From this study, a number of inhibitors were identified which displayed potent inhibition of CA $\left(K_{\mathrm{i}} \leq 10 \mathrm{nM}\right)$. Importantly, many also targeted transmembrane anchored CAs with very good selectivity over off-target cytosolic isozymes I and II. In particular, four standout cancerassociated CA selective inhibitors were identified; these were the acylated compound $\mathbf{1 7}$ and the free sugar compounds 26, 34 and 35, while six standout CA XIV inhibitors were also identified, compounds $\mathbf{1 7}, \mathbf{2 6}, \mathbf{2 8}, \mathbf{3 2}, \mathbf{3 4}$ and $\mathbf{3 5}$. The ideal potency-selectivity profile of these compounds is a much sought after characteristic for CA inhibitors and our results represent an important finding for the provision of good lead compound CA inhibitors with therapeutic potential. The molecules in this study also provide candidates with the possibility of dual-action for inhibition of extracellular CAs (IX, XII and XIV) - either directly as free sugars (membrane impermeable) or indirectly as acetylated sugar prodrugs, becoming free sugars upon nonspecific esterase hydrolysis. The application of acetate esters as a prodrug strategy to mask polar hydroxyl groups is prevalent across medicinal chemistry. ${ }^{44}$ The prodrugs often survive the gastrointestinal tract and are absorbed into the bloodstream where they are then hydrolyzed by nonspecific plasma esterases. ${ }^{45}$ An additional property of the free sugar thioureido glycoconjugates 25-40 was high water solubility. Finally, we have demonstrated the interrogation of CA active site via a carbohydrate tail moiety and thiourea linker to the benzene sulfonamide moiety common to all 32 inhibitors in this study. These compounds may constitute ideal leads for the development of safe and efficacious CA inhibitorbased therapeutics, providing further support for the significance of glycoconjugates in CA-based inhibitor development.

\section{Experimental section}

\subsection{General}


All starting materials and reagents, including per- $O$-acetylated sugars, were purchased from commercial suppliers. Reactions were monitored by TLC and TLC plates visualized with short wave UV fluorescence $(\lambda=254 \mathrm{~nm})$, sulfuric acid stain $\left(5 \% \mathrm{H}_{2} \mathrm{SO}_{4}\right.$ in ethanol) and/or orcinol stain (1 g of orcinol monohydrate in a mixture of EtOH: $\mathrm{H}_{2} \mathrm{O}: \mathrm{H}_{2} \mathrm{SO}_{4}$ 72.5:22.5:5). Silica gel flash chromatography was performed using silica gel $60 \AA$ (230-400 mesh). ${ }^{1} \mathrm{H}$ NMR spectra were acquired at $500 \mathrm{MHz}$ and ${ }^{13} \mathrm{C}$ NMR spectra at $125 \mathrm{MHz}$. Chemical shifts for ${ }^{1} \mathrm{H}$ and ${ }^{13} \mathrm{C}$ NMR spectra obtained in DMSO- $d_{6}$ are reported in ppm relative to residual solvent proton $(\delta=2.50 \mathrm{ppm})$ and carbon $(\delta=39.5 \mathrm{ppm})$ signals, respectively. Chemical shifts for ${ }^{1} \mathrm{H}$ NMR spectra obtained in $\mathrm{CDCl}_{3}$ are reported in ppm relative to residual solvent proton $(\delta=7.26 \mathrm{ppm})$. NMR in $\mathrm{D}_{2} \mathrm{O}$ are reported in ppm relative to residual solvent proton $(\delta=4.79 \mathrm{ppm}) .{ }^{13} \mathrm{C}$ NMR spectra in $\mathrm{D}_{2} \mathrm{O}$ are uncorrected. Multiplicity is indicated as follows: $\mathrm{s}$ (singlet); $\mathrm{d}$ (doublet); $\mathrm{vt}$ (virtual triplet); $\mathrm{t}$ (triplet); m (multiplet); dd (doublet of doublet); ddd (doublet of doublet of doublet); br (broad). Coupling constants are reported in hertz $(\mathrm{Hz})$. Aromatic protons ortho to the sulfonamide moiety

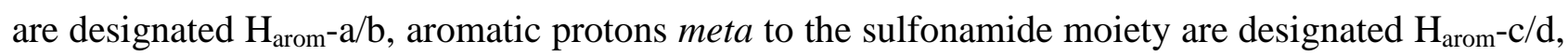
while aromatic protons with overlapped signals are designated $\mathrm{H}_{\text {arom }}$. Carbons in the ortho-position

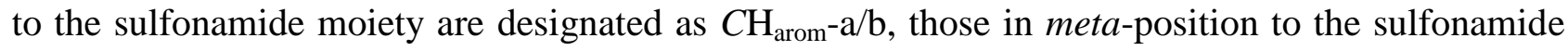

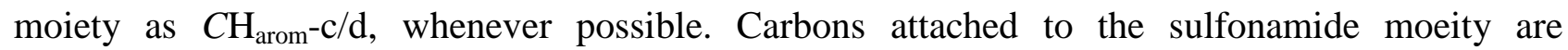
designated $C_{\text {arom }}-\mathrm{SO}_{2} \mathrm{NH}_{2}$ with the other aromatic quaternery carbons as $C_{\text {arom }}$. Melting points are uncorrected. Mass spectra (low and high resolution) were recorded using electrospray as the ionization technique in positive ion or negative ion modes as stated. All MS analysis samples were prepared as solutions in methanol. Purity of all compounds was $\geq 95 \%$.

4.1.2. General procedure 1: Synthesis of glycoconjugate benzene sulfonamides (9-24). To a solution of per- $O$-acetylated isothiocyanate derivative 5-8 (1.0 equiv) in acetonitrile was added sulfonamide 1-4 (1.0 equiv for $\mathbf{2}$ and 3, 2 equiv for $\mathbf{1}$ and $\mathbf{4}$ ) and DIPEA (1.0 equiv, for $\mathbf{2}$ only). The reaction was stirred at $40{ }^{\circ} \mathrm{C}$ until the starting material was consumed as evidenced by TLC ( $2 \mathrm{~h}$ for $\mathbf{2}$ and 3, 1-2 days for $\mathbf{1}$ and 4). The reaction mixture was then cooled to room temperature, concentrated and the residue diluted in ethyl acetate and washed with $1.0 \mathrm{M}$ aqueous $\mathrm{HCl}(3 \times)$ and water (1x). The aqueous extracts were combined and back extracted with ethyl acetate $(1 \times)$. The organic extracts were combined, dried over $\mathrm{MgSO}_{4}$, filtered and evaporated. If necessary the product was purified by column chromatography (eluant 2:1 to 1:3 hexanes-EtOAc) to give $64-98$ $\%$ yields. 


\subsubsection{General procedure 2: Deprotection of thiourea-bridged glycoconjugates $(9-24 \rightarrow 25-40)$.}

Deprotected compounds $\mathbf{2 5 - 4 0}$ were prepared by dissolving the corresponding per- $O$-acetylated precursor 9-24 in anhydrous methanol and treating with methanolic sodium methoxide $(25 \% \mathrm{w} / \mathrm{v}$, $0.1 \mathrm{M}$ final concentration, $\mathrm{pH}$ 9-12) at room temperature. Reactions were found to be complete within 30 minutes to $2 \mathrm{~h}$ by TLC. Neutralization of the reaction mixture by Amberlite IR-120 acidic ion exchange resin, followed by filtration and evaporation of the filtrate, followed by dissolving the residue in water and lyophilization afforded pure material by ${ }^{1} \mathrm{H}$ NMR and ${ }^{13} \mathrm{C}$ NMR spectroscopy. Yields $86-95 \%$.

\subsection{4. $N$-[4-(Aminosulfonyl)phenyl]- $N^{\prime}-\left(2^{\prime}, 3^{\prime}, 4^{\prime}, 6^{\prime}\right.$-tetra- $O$-acetyl-D-glucopyranosyl)thiourea (9)}

The title compound $\mathbf{9}$ was prepared from amine $\mathbf{1}$ and isothiocyanate $\mathbf{5}$ according to general procedure 1 to give a white solid. m.p. $=124-126{ }^{\circ} \mathrm{C} ;{ }^{1} \mathrm{H} \mathrm{NMR}\left(500 \mathrm{MHz}, \mathrm{CDCl}_{3}\right) \delta=8.79(\mathrm{~s}, 1 \mathrm{H}$, $\mathrm{NH}), 7.73\left(\mathrm{~d}, J=8.6 \mathrm{~Hz}, 2 \mathrm{H}, \mathrm{H}_{\text {arom }}-\mathrm{c} / \mathrm{d}\right), 7.53\left(\mathrm{~d}, J=8.7 \mathrm{~Hz}, 2 \mathrm{H}, \mathrm{H}_{\text {arom }}-\mathrm{a} / \mathrm{b}\right), 7.14(\mathrm{~d}, J=8.5 \mathrm{~Hz}$, $1 \mathrm{H}, \mathrm{CHNH}), 5.79$ (vt, $J=8.9 \mathrm{~Hz}, 1 \mathrm{H}, \mathrm{H}-1), 5.33-5.39$ (m, 3H, H-3, $\mathrm{SO}_{2} \mathrm{NH}_{2}$ ), 5.13 (vt, $J=10.2 \mathrm{~Hz}$, 1H, H-4), 5.08 (vt, $J=9.4 \mathrm{~Hz}, 1 \mathrm{H}, \mathrm{H}-2$ ), 4.58 (dd, $J=6.1,12.6 \mathrm{~Hz}, 1 \mathrm{H}, \mathrm{H}-6 \mathrm{a}$ ), 4.02 (dd, $J=0.9$, $12.2 \mathrm{~Hz}, 1 \mathrm{H}, \mathrm{H}-6 \mathrm{~b}), 3.89$ (ddd, $J=1.8,6.2,10.2 \mathrm{~Hz}, 1 \mathrm{H}, \mathrm{H}-5), 2.11,2.08,2.07(3 \times \mathrm{s}, 12 \mathrm{H}$, $\left.\mathrm{OCOCH}_{3}\right)$, assignments were confirmed by ${ }^{1} \mathrm{H}-{ }^{1} \mathrm{H}$ gCOSY.${ }^{13} \mathrm{C}$ NMR $\left(125 \mathrm{MHz}\right.$, DMSO- $\left.d_{6}\right) \delta=$ $181.9(\mathrm{C}=\mathrm{S}), 169.9,169.4,169.4169 .3\left(\mathrm{COCH}_{3}\right), 141.9\left(C_{\text {arom }}-\mathrm{SO}_{2} \mathrm{NH}_{2}\right), 139.4\left(\mathrm{C}_{\text {arom }}\right), 126.2$

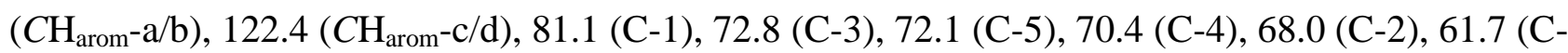
6), 20.5. 20.4, 20.4, $20.3\left(\mathrm{OCOCH}_{3}\right)$, assignments were confirmed by ${ }^{1} \mathrm{H}_{-}{ }^{13} \mathrm{C}$ HSQC. HRMS: Calcd for $\mathrm{C}_{21} \mathrm{H}_{28} \mathrm{~N}_{3} \mathrm{O}_{11} \mathrm{~S}_{2}{ }^{+}$562.1160, Found 562.1183.

\subsection{5. $\quad N$-[4-(Aminosulfonyl)benzyl $]-N^{\prime}-\left(2^{\prime}, 3^{\prime}, 4^{\prime}, 6^{\prime}\right.$-tetra- $O$-acetyl-D-glucopyranosyl)thiourea} (10)

The title compound $\mathbf{1 0}$ was prepared from amine $\mathbf{2}$ and isothiocyanate $\mathbf{5}$ according to general procedure 1 to give a white solid. m.p. $=121-122{ }^{\circ} \mathrm{C} ;{ }^{1} \mathrm{H} \mathrm{NMR}\left(500 \mathrm{MHz}, \mathrm{CDCl}_{3}\right) \delta=7.73(\mathrm{~d}, J=$ $\left.8.0 \mathrm{~Hz}, 2 \mathrm{H}, \mathrm{H}_{\text {arom }}-\mathrm{c} / \mathrm{d}\right), 7.38\left(\mathrm{~d}, J=8.3 \mathrm{~Hz}, 2 \mathrm{H}, \mathrm{H}_{\text {arom }}-\mathrm{a} / \mathrm{b}\right), 7.20\left(\mathrm{t}, J=5.6 \mathrm{~Hz}, 1 \mathrm{H}, \mathrm{NH}-\mathrm{CH}_{2}\right), 6.93$ $(\mathrm{d}, J=8.5 \mathrm{~Hz}, 1 \mathrm{H}, \mathrm{CHNH}), 5.79(\mathrm{vt}, J=8.7 \mathrm{~Hz}, 1 \mathrm{H}, \mathrm{H}-1), 5.44\left(\mathrm{~s}, 2 \mathrm{H}, \mathrm{SO}_{2} \mathrm{NH}_{2}\right), 5.36$ (vt, $J=9.4$ Hz 1H, H-3), 4.99-5.09 (m, 2H, H-2, H-4), 4.91-4.77 (m, 2H, NH-CH $)$, 4.58 (dd, $J=4.8,12.5$ Hz, 1H, H-6a), 4.02 (dd, $J=2.0,12.5$ Hz, 1H, H-6b), 3.89 (ddd, $J=2.2,4.6,10.1 \mathrm{~Hz}, 1 \mathrm{H}, \mathrm{H}-5$ ), 2.04, 2.03, 2.03, $2.01\left(4 \times \mathrm{s}, 12 \mathrm{H}, \mathrm{OCOCH}_{3}\right)$, assignments were confirmed by ${ }^{1} \mathrm{H}-{ }^{1} \mathrm{H}$ gCOSY.${ }^{13} \mathrm{C}$ NMR $\left(125 \mathrm{MHz}, \mathrm{CDCl}_{3}\right) \delta=184.4(\mathrm{C}=\mathrm{S}), 171.5,171.1,170.0,169.6\left(C \mathrm{OCH}_{3}\right), 143.1\left(C_{\mathrm{arom}}-\mathrm{SO}_{2} \mathrm{NH}_{2}\right)$, $140.1\left(\mathrm{C}_{\text {arom }}\right), 128.3\left(\mathrm{CH}_{\text {arom }} \mathrm{a} / \mathrm{b}\right), 126.6\left(\mathrm{CH}_{\text {arom }}-\mathrm{c} / \mathrm{d}\right), 82.8(\mathrm{C}-1), 73.5(\mathrm{C}-5), 73.2(\mathrm{C}-3), 71.0(\mathrm{C}-2)$, 
68.6 (C-4), 62.1 (C-6), $48.0\left(\mathrm{NHCH}_{2}\right), 20.9,20.9,20.8,20.7\left(\mathrm{OCOCH}_{3}\right)$, assignments were confirmed by ${ }^{1} \mathrm{H}_{-}{ }^{13} \mathrm{C}$ HSQC. HRMS: Calcd for $\mathrm{C}_{22} \mathrm{H}_{29} \mathrm{~N}_{3} \mathrm{O}_{11} \mathrm{~S}_{2} \mathrm{Na}^{+} 598.1136$, Found 598.1142.

\subsection{6. $N$-[4-(Aminosulfonyl)phenethyl]- $N^{\prime}-\left(2^{\prime}, 3^{\prime}, 4^{\prime}, 6^{\prime}\right.$-tetra- $O$-acetyl-D-glucopyranosyl)thiourea} (11)

The title compound $\mathbf{1 1}$ was prepared from amine $\mathbf{3}$ and isothiocyanate $\mathbf{5}$ according to general procedure 1 to give a white solid. m.p. $=116-118{ }^{\circ} \mathrm{C} ;{ }^{1} \mathrm{H} \mathrm{NMR}\left(500 \mathrm{MHz}, \mathrm{DMSO}-d_{6}\right) \delta=7.96(\mathrm{~d}$, $J=7.3 \mathrm{~Hz}, 1 \mathrm{H}, \mathrm{CHNH}), 7.82\left(\mathrm{brs}, 1 \mathrm{H}, \mathrm{N} H-\mathrm{CH}_{2}\right), 7.75\left(\mathrm{~d}, J=8.1 \mathrm{~Hz}, 2 \mathrm{H}, \mathrm{H}_{\text {arom }}-\mathrm{c} / \mathrm{d}\right), 7.40(\mathrm{~d}, J=$ $8.1 \mathrm{~Hz}, 2 \mathrm{H}, \mathrm{H}_{\text {arom}}-\mathrm{a} / \mathrm{b}$ ), 7.27 (s, 2H, SO $\mathrm{NH}_{2}$ ), 5.80 (brs, $1 \mathrm{H}, \mathrm{H}-1$ ), 5.32 (vt, J = 9.5 Hz 1H, H-3), 4.96-4.84 (m, 2H, H-2, H-4), 4.17 (dd, $J=4.8,12.5$ Hz, 1H, H-6a), 4.01-3.93 (m, 2H, H-5, H-6b), 3.68 (brs, $2 \mathrm{H}, \mathrm{NH}-\mathrm{CH}_{2}$ ), 2.90 (brs, $2 \mathrm{H}, \mathrm{CH}_{2} \mathrm{C}_{\text {arom}}$ ), 1.99, 1.99, 1.96, $1.94\left(4 \times \mathrm{s}, 12 \mathrm{H}, \mathrm{OCOCH}_{3}\right.$ ), assignments were confirmed by ${ }^{1} \mathrm{H}-{ }^{1} \mathrm{H}$ gCOSY.${ }^{13} \mathrm{C}$ NMR $\left(125 \mathrm{MHz}, \mathrm{DMSO}-d_{6}\right) \delta=183.6(\mathrm{C}=\mathrm{S})$, 169.9, 169.4, $169.3(4 \times \mathrm{C}=\mathrm{O}), 143.3\left(C_{\text {arom }}-\mathrm{SO}_{2} \mathrm{NH}_{2}\right), 142.1\left(\mathrm{C}_{\text {arom }}\right), 129.1\left(C_{\text {arom }}-\mathrm{a} / \mathrm{b}\right), 125.7$ $\left(\mathrm{CH}_{\text {arom-c}}{ }^{-\mathrm{c}} \mathrm{d}\right), 81.3,(\mathrm{C}-1), 72.8(\mathrm{C}-3), 72.0(\mathrm{C}-5), 70.5(\mathrm{C}-2), 67.9(\mathrm{C}-4), 61.6(\mathrm{C}-6), 44.8\left(\mathrm{CH}_{2} \mathrm{NH}\right)$, $34.0\left(\mathrm{CH}_{2} \mathrm{C}_{\text {arom }}\right), 20.5,20.4,20.3\left(4 \times \mathrm{OCOCH}_{3}\right)$, assignments were confirmed by ${ }^{1} \mathrm{H}-{ }^{13} \mathrm{C}$ HSQC. HRMS: Calcd for $\mathrm{C}_{23} \mathrm{H}_{31} \mathrm{~N}_{3} \mathrm{O}_{11} \mathrm{~S}_{2} \mathrm{Na}^{+}$612.1292, Found 612.1274.

\subsection{7. \\ $N$-[4-(Aminosulfonyl)phenylhydrazido]- $N^{\prime}-\left(2^{\prime}, 3^{\prime}, 4^{\prime}, 6^{\prime}\right.$-tetra- $O$-acetyl-D-} glucopyranosyl)thiourea (12)

The title compound $\mathbf{1 2}$ was prepared from amine $\mathbf{4}$ and isothiocyanate $\mathbf{5}$ according to general procedure 1 to give a white solid. m.p. $=149-151{ }^{\circ} \mathrm{C} ;{ }^{1} \mathrm{H}$ NMR $\left(500 \mathrm{MHz}, \mathrm{DMSO}-d_{6}\right) \delta=10.49$ (s, 1H, NH), 9.87 (s, 1H, NH), 8.54 (d, J=8.7 Hz, 1H, NHCH), 8.04 (d, J=8.2 Hz, 2H, Harom-c/d), $7.91\left(\mathrm{~d}, J=8.0 \mathrm{~Hz}, 2 \mathrm{H}, \mathrm{H}_{\text {arom }} \mathrm{a} / \mathrm{b}\right.$ ), 7.50 (s, 2H, $\mathrm{SO}_{2} \mathrm{NH}_{2}$ ), 5.89 (vt, $\left.J=9.0 \mathrm{~Hz}, 1 \mathrm{H}, \mathrm{H}-1\right), 5.31$ (vt, $J$ $=9.3 \mathrm{~Hz}, 1 \mathrm{H}, \mathrm{H}-3), 5.08$ (vt, $J=9.2 \mathrm{~Hz}, 1 \mathrm{H}, \mathrm{H}-2), 4.89$ (vt, $J=9.5 \mathrm{~Hz}, 1 \mathrm{H}, \mathrm{H}-4), 4.27$ (dd, $J=$

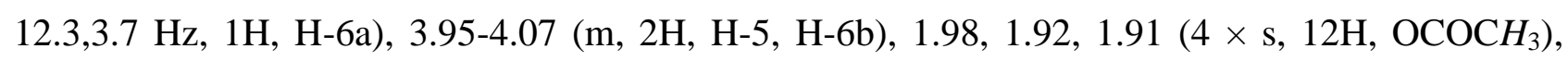
assignments were confirmed by ${ }^{1} \mathrm{H}-{ }^{1} \mathrm{H}$ gCOSY.${ }^{13} \mathrm{C}$ NMR $\left(125 \mathrm{MHz}, \mathrm{DMSO}-d_{6}\right) \delta=183.2(\mathrm{C}=\mathrm{S})$, 169.9, 169.4, 169.2, $169.1\left(\mathrm{COCH}_{3}\right), 165.1(\mathrm{NHC}=\mathrm{O}), 146.8\left(C_{\mathrm{arom}}-\mathrm{SO}_{2} \mathrm{NH}_{2}\right), 135.3\left(\mathrm{C}_{\text {arom }}\right), 128.6$ $\left(\mathrm{CH}_{\text {arom }}{ }^{-\mathrm{a}} / \mathrm{b}\right), 125.3\left(\mathrm{CH}_{\text {arom }}{ }^{\mathrm{c}} / \mathrm{d}\right), 82.0(\mathrm{C}-1), 72.8(\mathrm{C}-3), 72.2(\mathrm{C}-5), 70.4(\mathrm{C}-2), 67.7(\mathrm{C}-4), 61.6(\mathrm{C}-$ 6), 20.5. 20.4, 20.3, $20.3\left(\mathrm{OCOCH}_{3}\right)$, assignments were confirmed by ${ }^{1} \mathrm{H}_{-}{ }^{13} \mathrm{C}$ HSQC. HRMS: Calcd for $\mathrm{C}_{22} \mathrm{H}_{29} \mathrm{~N}_{4} \mathrm{O}_{12} \mathrm{~S}_{2} 605.1218$, Found 605.1247.

4.1.8. $N$-[4-(Aminosulfonyl)phenyl]- $N^{\prime}-\left(2^{\prime}, 3^{\prime}, 4^{\prime}, 6^{\prime}\right.$-tetra- $O$-acetyl-D-galactopyranosyl)thiourea (13) 
The title compound $\mathbf{1 3}$ was prepared from amine $\mathbf{1}$ and isothiocyanate $\mathbf{6}$ according to general procedure 1 to give a white solid. m.p. $=132-134{ }^{\circ} \mathrm{C} ;{ }^{1} \mathrm{H} \mathrm{NMR}\left(500 \mathrm{MHz}, \mathrm{CDCl}_{3}\right) \delta=8.86(\mathrm{~s}, 1 \mathrm{H}$, $\mathrm{NH}), 7.71\left(\mathrm{~d}, J=8.5 \mathrm{~Hz}, 2 \mathrm{H}, \mathrm{H}_{\text {arom}}-\mathrm{c} / \mathrm{d}\right), 7.54$ (d, $J=8.4 \mathrm{~Hz}, 2 \mathrm{H}, \mathrm{H}_{\text {arom-a/b) }}{ }^{-} 7.20$ (d, $J=8.3 \mathrm{~Hz}$, $1 \mathrm{H}, \mathrm{CHNH}$ ), 5.81 (vt, $J=9.0 \mathrm{~Hz}, 1 \mathrm{H}, \mathrm{H}-1), 5.57-5.47$ (m, 3H, H-4, $\mathrm{SO}_{2} \mathrm{NH}_{2}$ ), 5.31 (vt, $J=9.6 \mathrm{~Hz}$, $1 \mathrm{H}, \mathrm{H}-2), 5.23$ (dd, $J=3.4,10.1 \mathrm{~Hz}, 1 \mathrm{H}, \mathrm{H}-3), 4.50$ (dd, $J=7.1,11.5 \mathrm{~Hz}, 1 \mathrm{H}, \mathrm{H}-6 \mathrm{a}), 4.11$ (ddd, $J=$ 4.3, 7.1, 10.5 Hz, 1H, H-5), 4.02 (dd, J = 4.3, $11.5 \mathrm{~Hz}, 1 \mathrm{H}, \mathrm{H}-6 \mathrm{~b}), 2.18,2.08,2.01,1.98$ (4 × s, 12H, $\left.\mathrm{OCOCH}_{3}\right)$, assignments were confirmed by ${ }^{1} \mathrm{H}-{ }^{1} \mathrm{H}$ gCOSY. ${ }^{13} \mathrm{C} \mathrm{NMR}\left(125 \mathrm{MHz}, \mathrm{CDCl}_{3}\right) \delta=$ $182.3(\mathrm{C}=\mathrm{S}), 171.7,171.3,170.5,169.7\left(\mathrm{COCH}_{3}\right), 141.5\left(C_{\text {arom }}-\mathrm{SO}_{2} \mathrm{NH}_{2}\right), 138.7\left(\mathrm{C}_{\text {arom }}\right), 127.1$ $\left(\mathrm{CH}_{\text {arom}}-\mathrm{a} / \mathrm{b}\right), 124.3\left(\mathrm{CH}_{\text {arom }}-\mathrm{c} / \mathrm{d}\right), 83.4(\mathrm{C}-1), 74.4(\mathrm{C}-5), 71.6(\mathrm{C}-3), 68.3(\mathrm{C}-2), 68.0(\mathrm{C}-4), 62.4(\mathrm{C}-$ 6), 21.2. 21.0, 20.8, $20.6\left(\mathrm{OCOCH}_{3}\right)$, assignments were confirmed by ${ }^{1} \mathrm{H}_{-}{ }^{13} \mathrm{C}$ HSQC. HRMS: Calcd for $\mathrm{C}_{21} \mathrm{H}_{28} \mathrm{~N}_{3} \mathrm{O}_{11} \mathrm{~S}_{2}{ }^{+}$562.1160, Found 562.1182.

\subsection{9. $\quad N$-[4-(Aminosulfonyl)benzyl]- $N^{\prime}-\left(2^{\prime}, 3^{\prime}, 4^{\prime}, 6^{\prime}\right.$-tetra- $O$-acetyl-D-galactopyranosyl)thiourea} (14)

The title compound $\mathbf{1 4}$ was prepared from amine $\mathbf{2}$ and isothiocyanate $\mathbf{6}$ according to general procedure 1 to give a white solid. m.p. $=115-117^{\circ} \mathrm{C} ;{ }^{1} \mathrm{H}$ NMR $\left(500 \mathrm{MHz}, \mathrm{DMSO}-d_{6}\right) \delta=8.25(\mathrm{~d}$, $J=9.3 \mathrm{~Hz}, 1 \mathrm{H}, \mathrm{CHNH}), 8.20$ (brs, $\left.1 \mathrm{H}, \mathrm{N} H-\mathrm{CH}_{2}\right), 7.78\left(\mathrm{~d}, J=8.2 \mathrm{~Hz}, 2 \mathrm{H}, \mathrm{H}_{\text {arom }}-\mathrm{c} / \mathrm{d}\right), 7.40(\mathrm{~d}, J=$ $8.1 \mathrm{~Hz}, 2 \mathrm{H}, \mathrm{H}_{\text {arom-a/b) }} 7.30$ (s, 2H, $\mathrm{SO}_{2} \mathrm{NH}_{2}$ ), 5.83 (brs, $1 \mathrm{H}, \mathrm{H}-1$ ), 5.34-5.28 (m, 2H, H-3, H-4), 5.05 (vt, $J=8.9 \mathrm{~Hz}, 1 \mathrm{H}, \mathrm{H}-2), 4.83$ (dd, $\left.J=4.3,15.9 \mathrm{~Hz}, 1 \mathrm{H}, \mathrm{NHCH}_{2} \mathrm{a}\right), 4.74$ (dd, $J=5.6,15.8 \mathrm{~Hz}$, $1 \mathrm{H}, \mathrm{NHCH}_{2} \mathrm{~b}$ ), 4.30-4.24 (m, 1H, H-5), 4.07-4.01 (m, 2H, H-6a/b), 2.12, 1.99, 1.99, 1.94 (4 × s, $\left.12 \mathrm{H}, \mathrm{OCOCH} \mathrm{H}_{3}\right)$, assignments were confirmed by ${ }^{1} \mathrm{H}-{ }^{1} \mathrm{H}$ gCOSY$.{ }^{13} \mathrm{C} \mathrm{NMR}\left(125 \mathrm{MHz}, \mathrm{CDCl}_{3}\right) \delta=$ $184.0(\mathrm{C}=\mathrm{S}), 170.3,169.8,169.5,169.3\left(\mathrm{COCH}_{3}\right), 142.9\left(C_{\text {arom }}-\mathrm{SO}_{2} \mathrm{NH}_{2}\right), 142.7\left(\mathrm{C}_{\text {arom }}\right), 127.3$ $\left(\mathrm{CH}_{\text {arom }}{ }^{-\mathrm{a}} / \mathrm{b}\right), 125.6\left(\mathrm{CH}_{\text {arom }}-\mathrm{c} / \mathrm{d}\right), 81.9(\mathrm{C}-1), 71.2(\mathrm{C}-5), 70.7(\mathrm{C}-3), 68.5(\mathrm{C}-2), 67.5(\mathrm{C}-4), 61.2(\mathrm{C}-$ 6), $46.6\left(\mathrm{NHCH}_{2}\right), 20.5,20.4,20.4,20.3\left(\mathrm{OCOCH}_{3}\right)$, assignments were confirmed by ${ }^{1} \mathrm{H}_{-}{ }^{13} \mathrm{C}$ HSQC. HRMS: Calcd for $\mathrm{C}_{22} \mathrm{H}_{29} \mathrm{~N}_{3} \mathrm{O}_{11} \mathrm{~S}_{2} \mathrm{Na}^{+}$598.1136, Found 598.1132.

\subsubsection{0.}

$N$-[4-(Aminosulfonyl)phenethyl]- $N^{\prime}-\left(2^{\prime}, 3^{\prime}, 4^{\prime}, 6^{\prime}\right.$-tetra- $O$-acetyl-D-

\section{galactopyranosyl)thiourea (15)}

The title compound $\mathbf{1 5}$ was prepared from amine $\mathbf{3}$ and isothiocyanate $\mathbf{6}$ according to general procedure 1 to give a white solid. m.p. $=113-115^{\circ} \mathrm{C} ;{ }^{1} \mathrm{H}$ NMR $\left(500 \mathrm{MHz}, \mathrm{DMSO}-d_{6}\right) \delta=8.04(\mathrm{~d}$, $J=9.0 \mathrm{~Hz}, 1 \mathrm{H}, \mathrm{NHCH}), 7.75\left(\mathrm{~d}, J=8.0 \mathrm{~Hz}, 2 \mathrm{H}, \mathrm{H}_{\text {arom }}-\mathrm{c} / \mathrm{d}\right), 7.71$ (brs, $\left.1 \mathrm{H}, \mathrm{N} H-\mathrm{CH}_{2}\right), 7.40(\mathrm{~d}, J=$ $8.1 \mathrm{~Hz}, 2 \mathrm{H}, \mathrm{H}_{\text {arom-a/b) }} 7.28$ (s, 2H, $\mathrm{SO}_{2} \mathrm{NH}_{2}$ ), 5.80 (brs, 1H, H-1), 5.32-5.26 (m, 2H, H-3, H-4), 5.01 (vt, $J=7.6 \mathrm{~Hz}, 1 \mathrm{H}, \mathrm{H}-2), 4.28-4.20$ (m, 1H, H-5), 4.02-3.98 (m, 2H, H-6a/b), 3.68 (brs, 2H, $\mathrm{CH}_{2} \mathrm{NH}$ ), 2.90 (brs, $2 \mathrm{H}, \mathrm{CH}_{2} \mathrm{C}_{\text {arom }}$ ) 2.10, 1.98, $1.92\left(3 \times \mathrm{s}, 12 \mathrm{H}, \mathrm{OCOCH}_{3}\right)$, assignments were 
confirmed by ${ }^{1} \mathrm{H}-{ }^{1} \mathrm{H}$ gCOSY. ${ }^{13} \mathrm{C}$ NMR (125 MHz, DMSO- $\left.d_{6}\right) \delta=183.6(\mathrm{C}=\mathrm{S}), 169.8,169.5$, $169.3(4 \times \mathrm{C}=\mathrm{O}), 143.3\left(C_{\text {arom }}-\mathrm{SO}_{2} \mathrm{NH}_{2}\right), 142.1\left(\mathrm{C}_{\text {arom }}\right), 129.1\left(C_{\mathrm{arom}}-\mathrm{a} / \mathrm{b}\right), 125.7\left(\mathrm{CH}_{\mathrm{arom}}-\mathrm{c} / \mathrm{d}\right)$, 81.6, (C-1), 71.1 (C-5), 70.7 (C-3), 68.4 (C-2), 67.5 (C-4), 61.2 (C-6), 44.8 (NH-CH2), 34.0 $\left(\mathrm{CH}_{2} \mathrm{C}_{\text {arom }}\right), 20.5,20.4,20.4,20.3\left(\mathrm{OCOCH}_{3}\right)$, assignments were confirmed by ${ }^{1} \mathrm{H}-{ }^{13} \mathrm{C}$ HSQC. HRMS: Calcd for $\mathrm{C}_{23} \mathrm{H}_{32} \mathrm{~N}_{3} \mathrm{O}_{11} \mathrm{~S}_{2}{ }^{+}$590.1473, Found 590.1493.

\subsubsection{1. $\quad N$-[4-(Aminosulfonyl)phenylhydrazido]- $N^{\prime}-\left(2^{\prime}, 3^{\prime}, 4^{\prime}, 6^{\prime}\right.$-tetra- $O$-acetyl-D- galactopyranosyl)thiourea (16)}

The title compound $\mathbf{1 6}$ was prepared from amine $\mathbf{4}$ and isothiocyanate $\mathbf{6}$ according to general procedure 1 to give a white solid. m.p. $=194-195{ }^{\circ} \mathrm{C} ;{ }^{1} \mathrm{H}$ NMR $\left(500 \mathrm{MHz}, \mathrm{DMSO}-d_{6}\right) \delta=10.43$ (s, 1H, NH), $9.86(\mathrm{~s}, 1 \mathrm{H}, \mathrm{NH}), 8.61$ (d, J=8.5 Hz, 1H, CHNH), 8.06 (d, J=8.0 Hz, 2H, $\left.\mathrm{H}_{\text {arom }}-\mathrm{c} / \mathrm{d}\right)$, $7.93\left(\mathrm{~d}, J=8.0 \mathrm{~Hz}, 2 \mathrm{H}, \mathrm{H}_{\mathrm{arom}} \mathrm{-a} / \mathrm{b}\right), 7.53$ (s, 2H, $\mathrm{SO}_{2} \mathrm{NH}_{2}$ ), 5.84 (vt, $\left.J=9.1 \mathrm{~Hz}, 1 \mathrm{H}, \mathrm{H}-1\right), 5.34-5.26$ (m, 2H, H-3, H-4), 5.17 (vt, $J=9.3 \mathrm{~Hz}, 1 \mathrm{H}, \mathrm{H}-2), 4.32-4.22$ (m, 1H, H-5), 4.07-3.99 (m, 2H, H$6 \mathrm{a} / \mathrm{b}), 2.08,2.00,1.94,1.89\left(4 \times \mathrm{s}, 12 \mathrm{H}, \mathrm{OCOCH}_{3}\right)$, assignments were confirmed by ${ }^{1} \mathrm{H}-{ }^{1} \mathrm{H}$ gCOSY. ${ }^{13} \mathrm{C}$ NMR $\left(125 \mathrm{MHz}, \mathrm{DMSO}-d_{6}\right) \delta=183.4(\mathrm{C}=\mathrm{S}), 169.8,169.4,169.3(4 \times \mathrm{C}=\mathrm{O}), 166.6$ $(\mathrm{NHC}=\mathrm{O}), 146.7\left(C_{\text {arom }}-\mathrm{SO}_{2} \mathrm{NH}_{2}\right), 128.6\left(\mathrm{CH}_{\text {arom }}-\mathrm{a} / \mathrm{b}\right), 125.3\left(\mathrm{CH}_{\text {arom }}-\mathrm{c} / \mathrm{d}\right), 82.4(\mathrm{C}-1), 71.6(\mathrm{C}-5)$, 70.8 (C-4), 68.0 (C-2), 67.6 (C-3), 61.2 (C-6), 20.5, 20.4, 20.3 (4 × $\mathrm{OCOCH}_{3}$ ), HRMS: Calcd for $\mathrm{C}_{22} \mathrm{H}_{29} \mathrm{~N}_{4} \mathrm{O}_{12} \mathrm{~S}_{2}^{+}$605.1218, Found 605.1231.

\subsubsection{2.}

$N$-[4-(Aminosulfonyl)phenyl]- $N^{\prime}-\left(2^{\prime}, 2^{\prime \prime}, 3^{\prime}, 3^{\prime \prime}, 4^{\prime \prime}, 6^{\prime}, 6^{\prime \prime}\right.$-hepta- $O$-acetyl-Dmaltosyl)thiourea (17)

The title compound $\mathbf{1 7}$ was prepared from amine $\mathbf{1}$ and isothiocyanate $\mathbf{7}$ according to general procedure 1 to give a yellow solid. m.p. $=178-179{ }^{\circ} \mathrm{C} ;{ }^{1} \mathrm{H}$ NMR $\left(500 \mathrm{MHz}, \mathrm{DMSO}-d_{6}\right) \delta=10.09$ (s, 1H, NH), 8.30 (brs, 1H, CHNH), 7.75 (d, J=8.8 Hz, 2H, $\mathrm{H}_{\text {arom }}-\mathrm{c} / \mathrm{d}$ ), 7.69 (d, J = 8.2 Hz, 2H, $\mathrm{H}_{\text {arom- }} \mathrm{a} / \mathrm{b}$ ), 7.28 (s, 2H, SO $\mathrm{NH}_{2}$ ), 5.85 (brs, 1H, H-1), 5.40 (vt, J = 8.6 Hz, 1H, H-3), 5.32 (d, J = 3.3, 1H, H-1'), 5.24 (vt, $J=10.0$ Hz, 1H, H-3'), 4.99 (vt, J=9.9 Hz, 1H, H-4), 4.94-4.84 (m, 2H, H2, H-2'), 4.35 (dd, $J=1.0,11.5$ Hz, 1H, H-6a), 4.21-4.13 (m, 2H, H-6'a, H-6b), 4.05-3.92 (m, 4H, H-4', H-5', H-5, H-6'b), 2.06, 2.02, 2.01, 1.99, 1.98, 1.97, 1.96 (7 × s, 21H, $\left.\mathrm{OCOCH}_{3}\right)$, assignments were confirmed by ${ }^{1} \mathrm{H}-{ }^{1} \mathrm{H}$ gCOSY. ${ }^{13} \mathrm{C}$ NMR $\left(125 \mathrm{MHz}, \mathrm{DMSO}-d_{6}\right) \delta=181.9(\mathrm{C}=\mathrm{S}), 170.1,169.9$, $169.8,169.6,169.5,169.5,169.4\left(\mathrm{COCH}_{3}\right), 142.0\left(C_{\text {arom }}-\mathrm{SO}_{2} \mathrm{NH}_{2}\right), 141.1\left(\mathrm{C}_{\text {arom }}\right), 126.2\left(C_{\text {arom }}{ }^{-}\right.$ a/b), $122.0\left(\mathrm{CH}_{\text {arom-c/d) }} 95.3\right.$ (C-1'), 82.0 (C-1), 75.5 (C-3), 74.9 (C-4), 73.7 (C-5), 71.4 (C-2), 70.1 (C-2'), 69.7 (C-3'), 68.35 (C-4'), 68.33 (C-5'), 63.2 (C-6), 61.7 (C-6'), 20.6. 20.6, 20.4, 20.4, 20.4, 20.3, $20.2\left(\mathrm{OCOCH}_{3}\right)$, assignments were confirmed by ${ }^{1} \mathrm{H}-{ }^{13} \mathrm{C} \mathrm{HSQC}$. 
4.1.13. $N$-[4-(Aminosulfonyl)benzyl]- $N^{\prime}-\left(2^{\prime}, 2^{\prime \prime}, 3^{\prime}, 3^{\prime \prime}, 4^{\prime}, 6^{\prime}, 6^{\prime \prime}\right.$-hepta- $O$-acetyl-Dmaltosyl)thiourea (18)

The title compound $\mathbf{1 8}$ was prepared from amine $\mathbf{2}$ and isothiocyanate $\mathbf{7}$ according to general procedure 1 to give a white solid. m.p. $=124-126{ }^{\circ} \mathrm{C} ;{ }^{1} \mathrm{H}$ NMR $\left(500 \mathrm{MHz}, \mathrm{DMSO}-d_{6}\right) \delta=8.27$ (brs, $\left.1 \mathrm{H}, \mathrm{NH}-\mathrm{CH}_{2}\right), 8.11$ (brs, $\left.1 \mathrm{H}, \mathrm{CHNH}\right), 7.77$ (d, $J=7.8 \mathrm{~Hz}, 2 \mathrm{H}, \mathrm{H}_{\text {arom }}-\mathrm{c} / \mathrm{d}$ ), 7.40 (d, $J=8.0 \mathrm{~Hz}$, $2 \mathrm{H}, \mathrm{H}_{\text {arom-a/b) }}{ }^{-} 7.29$ (s, 2H, $\mathrm{SO}_{2} \mathrm{NH}_{2}$ ), 5.78 (brs, 1H, H-1), 5.39-5.28 (m, 2H, H-1', H-3), 5.23 (vt, J $=10.0 \mathrm{~Hz}, 1 \mathrm{H}, \mathrm{H}-3$ '), 4.99 (vt, $J=9.7 \mathrm{~Hz}, 1 \mathrm{H}, \mathrm{H}-4$ '), $4.91-4.71$ (m, 4H, H-2, H-2', NH-CH $), 4.34$ (dd, $J=1,11.9 \mathrm{~Hz}, 1 \mathrm{H}, \mathrm{H}-6 \mathrm{a}), 4.21-4.11$ (m, 2H, H-5, H-6b), 4.06-3.89 (m, 4H, H-4, H-5', H6'a/b), 1.88, 1.86, 1.84, 1.82, 1.80, $1.78\left(6 \times \mathrm{s}, 21 \mathrm{H}, \mathrm{OCOCH}_{3}\right)$, assignments were confirmed by ${ }^{1} \mathrm{H}-$ ${ }^{1} \mathrm{H}$ gCOSY. ${ }^{13} \mathrm{C}$ NMR $\left(125 \mathrm{MHz}, \mathrm{CDCl}_{3}\right) \delta=178.0(\mathrm{C}=\mathrm{S}), 170.1,170.0,169.9,169.6,169.5,169.2$ $\left(7 \times \mathrm{COCH}_{3}\right), 142.7\left(C_{\mathrm{arom}}-\mathrm{SO}_{2} \mathrm{NH}_{2}\right), 130.2\left(\mathrm{C}_{\mathrm{arom}}\right), 127.4\left(\mathrm{CH}_{\mathrm{arom}}-\mathrm{a} / \mathrm{b}\right), 125.6\left(\mathrm{CH}_{\mathrm{arom}}-\mathrm{c} / \mathrm{d}\right), 95.3$ (C-1'), 74.9 (C-1), 73.7 (C-3), 72.8 (C-5'), 71.2 (C-2), 69.5 (C-2'), 68.94 (C-3'), 68.92 (C-5), 68.0 (C-4'), 67.8 (C-4), 62.9 (C-6), 62.9 (C-6'), $46.7\left(\mathrm{NH}-\mathrm{CH}_{2}\right)$, 20.6, 20.6, 20.4, 20.4, 20.3, 20.3 (7 × $\mathrm{OCOCH}_{3}$ ), assignments were confirmed by ${ }^{1} \mathrm{H}-{ }^{13} \mathrm{C}$ HSQC. HRMS: Calcd for $\mathrm{C}_{34} \mathrm{H}_{45} \mathrm{~N}_{3} \mathrm{O}_{19} \mathrm{~S}_{2} \mathrm{Na}^{+}$ 886.1981, Found 886.2003.

4.1.14. $\quad N$-[4-(Aminosulfonyl)phenylethyl]- $N^{\prime}-\left(2^{\prime}, 2^{\prime \prime}, 3^{\prime}, 3^{\prime \prime}, 4^{\prime \prime}, 6^{\prime}, 6^{\prime \prime}\right.$-hepta- $O$-acetyl-Dmaltosyl)thiourea (19)

The title compound $\mathbf{1 9}$ was prepared from amine $\mathbf{3}$ and isothiocyanate $\mathbf{7}$ according to general procedure 1 to give a white solid. m.p. $=130-131{ }^{\circ} \mathrm{C} ;{ }^{1} \mathrm{H}$ NMR $\left(500 \mathrm{MHz}, \mathrm{DMSO}-d_{6}\right) \delta=7.94$ (brs, $1 \mathrm{H}, \mathrm{NH}-\mathrm{CH}_{2}$ ), 7.80 (brs, $\left.1 \mathrm{H}, \mathrm{CHNH}\right), 7.75$ (d, $J=8.8 \mathrm{~Hz}, 2 \mathrm{H}, \mathrm{H}_{\text {arom }}-\mathrm{c} / \mathrm{d}$ ), 7.40 (d, J = 8.2 Hz, $2 \mathrm{H}, \mathrm{H}_{\text {arom-a/b) }} \mathrm{a} .28$ (s, 2H, $\mathrm{SO}_{2} \mathrm{NH}_{2}$ ), 5.76 (brs, $1 \mathrm{H}, \mathrm{H}-1$ ), 5.37-5.29 (m, 2H, H-1', H-3), 5.23 (vt, $J$ $\left.=10.1 \mathrm{~Hz}, 1 \mathrm{H}, \mathrm{H}-3^{\prime}\right), 4.99$ (vt, $\left.J=9.6 \mathrm{~Hz}, 1 \mathrm{H}, \mathrm{H}-4^{\prime}\right), 4.87$ (dd, $J=10.5,3.5 \mathrm{~Hz}, 1 \mathrm{H}, \mathrm{H}-2$ '), 4.78 (vt, $J=8.9 \mathrm{~Hz}, 1 \mathrm{H}, \mathrm{H}-2$ ), 4.33 (dd, $J=1.0,12.1 \mathrm{~Hz}, 1 \mathrm{H}, \mathrm{H}-6 \mathrm{a}), 4.20-4.13$ (m, 2H, H-6'a, H-6b), 4.043.95 (m, 2H, H-5', H-6'b), 3.94-3.90 (m, 2H, H-4, H-5), 3.73-3.63 (m, 2H, NH-CH $)$, 2.97-2.85 $\left(\mathrm{CH}_{2} \mathrm{C}_{\text {arom }}\right), 2.06,2.03,2.01,1.99,1.96,1.93\left(6 \times \mathrm{s}, 21 \mathrm{H}, \mathrm{OCOCH}_{3}\right)$, assignments were confirmed by ${ }^{1} \mathrm{H}-{ }^{1} \mathrm{H}$ gCOSY. ${ }^{13} \mathrm{C}$ NMR $\left(125 \mathrm{MHz}, \mathrm{DMSO}-d_{6}\right) \delta=177.3(\mathrm{C}=\mathrm{S}), 170.0,169.9,169.8,169.5$, 169.42, 169.40, $169.1\left(\mathrm{COCH}_{3}\right), 143.3\left(C_{\text {arom }}-\mathrm{SO}_{2} \mathrm{NH}_{2}\right), 142.1\left(\mathrm{C}_{\text {arom }}\right), 129.1\left(\mathrm{CH}_{\text {arom }}{ }^{-\mathrm{a}} / \mathrm{b}\right), 125.7$ $\left(\mathrm{CH}_{\text {arom}}\right.$-c/d), 95.3 (C-1'), 82.0 (C-1), 74.9 (C-3), 73.6 (C-4), 72.7 (C-5), 71.0 (C-2), 69.4 (C-2'), $68.9\left(\mathrm{C}^{\prime} 3^{\prime}\right), 67.9\left(\mathrm{C}^{\prime} 5^{\prime}\right), 67.8\left(\mathrm{C}-4^{\prime}\right), 62.9(\mathrm{C}-6), 61.4\left(\mathrm{C}-66^{\prime}\right), 44.8\left(\mathrm{CH}_{2} \mathrm{NH}\right), 30.6\left(\mathrm{CH}_{2} \mathrm{C}_{\text {arom }}\right), 20.6$. 20.5, 20.4, 20.4, 20.3, 20.3, $20.2\left(\mathrm{OCOCH}_{3}\right)$, assignments were confirmed by ${ }^{1} \mathrm{H}_{-}{ }^{13} \mathrm{C}$ HSQC. HRMS: Calcd for $\mathrm{C}_{35} \mathrm{H}_{48} \mathrm{~N}_{3} \mathrm{O}_{19} \mathrm{~S}_{2}{ }^{+} 878.2318$, Found 878.2296. 


\subsubsection{5. $\quad N$-[4-(Aminosulfonyl)phenylhydrazido]- $N^{\prime}-\left(2^{\prime}, 2^{\prime \prime}, 3^{\prime}, 3^{\prime \prime}, 4^{\prime \prime}, 6^{\prime}, 6^{\prime \prime}\right.$-hepta- $O$-acetyl-D-}

maltosyl)thiourea (20)

The title compound 20 was prepared from amine $\mathbf{4}$ and isothiocyanate $\mathbf{7}$ according to general procedure 1 to give a white solid. m.p. $=138-139{ }^{\circ} \mathrm{C} ;{ }^{1} \mathrm{H}$ NMR $\left(500 \mathrm{MHz}, \mathrm{DMSO}-d_{6}\right) \delta=10.49$ (s, 1H, NH), 9.87 (s, 1H, NH), 8.44 (s, 1H, NHCH), 8.02 (d, J=8.3 Hz, 2H, $\left.\mathrm{H}_{\text {arom }}-\mathrm{c} / \mathrm{d}\right), 7.91$ (brs, $2 \mathrm{H}, \mathrm{H}_{\text {arom-a/b) }} \mathrm{a} .49$ (s, 2H, $\mathrm{SO}_{2} \mathrm{NH}_{2}$ ), 5.84 (vt, J = 8.4 Hz, 1H, H-1), 5.34-5.26 (m, 2H, H-1', H-3'), 5.21 (t, $J=9.9 \mathrm{~Hz}, 1 \mathrm{H}, \mathrm{H}-3$ ), 5.00-4.94 (m, 2H, H-2, H-4), 4.85 (dd, $J=10.5,3.3$ Hz, 1H, H-2'), 4.34 (d, $J=12.8$ Hz, 1H, H-6a), 4.22-4.10 (m, 2H, H-5', H-6b), 4.02-3.94 (m, 3H, H-5, H-6'a/b), 3.85 (brs, 1H, H-4'), 2.05, 2.01, 1.99, 1.98, 1.95, 1.92, $189\left(7 \times \mathrm{s}, 21 \mathrm{H}, \mathrm{OCOCH}_{3}\right)$, assignments were confirmed by ${ }^{1} \mathrm{H}-{ }^{1} \mathrm{H}$ gCOSY. ${ }^{13} \mathrm{C}$ NMR $\left(125 \mathrm{MHz}, \mathrm{DMSO}-d_{6}\right) \delta=179.7(\mathrm{C}=\mathrm{S}), 170.0,169.9$, $169.9,169.5,169.4,169.4,169.1\left(\mathrm{COCH}_{3}\right), 166.3(\mathrm{NHC}=\mathrm{O}), 146.8\left(C_{\text {arom }}-\mathrm{SO}_{2} \mathrm{NH}_{2}\right), 140.6\left(\mathrm{C}_{\text {arom }}\right)$, $128.5\left(\mathrm{CH}_{\text {arom}}{ }^{-\mathrm{a}} / \mathrm{b}\right), 125.3\left(\mathrm{CH}_{\text {arom}}{ }^{-\mathrm{c}} / \mathrm{d}\right), 95.3(\mathrm{C}-1), 82.9$ (C-1), 79.2 (C-3), $74.5(\mathrm{C}-4), 73.6(\mathrm{C}-5)$, 72.9 (C-2), 69.5 (C-2'), 68.9 (C-3'), 67.9 (C-5'), 67.8 (C-4'), 62.8 (C-6), 61.3 (C-6'), 20.6, 20.6, 20.4, 20.3, $20.2\left(7 \times \mathrm{OCOCH}_{3}\right)$, assignments were confirmed by ${ }^{1} \mathrm{H}_{-}{ }^{13} \mathrm{C}$ HSQC. LRMS $\left(\mathrm{ESI}^{+}\right): \mathrm{m} / z=893$ $[\mathrm{M}+\mathrm{H}]^{+}$.

4.1.16.

$N$-[4-(Aminosulfonyl)phenyl]- $N^{\prime}-\left(2^{\prime}, 2^{\prime \prime}, 3^{\prime}, 3^{\prime \prime}, 4^{\prime \prime}, 6^{\prime}, 6^{\prime \prime}\right.$-hepta- $O$-acetyl-Dlactosyl)thiourea (21)

The title compound $\mathbf{2 1}$ was prepared from amine $\mathbf{1}$ and isothiocyanate $\mathbf{8}$ according to general procedure 1 to give a yellow solid. m.p. $=119-121^{\circ} \mathrm{C} .{ }^{1} \mathrm{H}$ NMR $\left(500 \mathrm{MHz}, \mathrm{DMSO}-d_{6}\right) \delta=10.10$ (s, 1H, NH), 8.40 (brs, 1H, CHNH), 7.75 (d, J = 8.5 Hz, 2H, $\mathrm{H}_{\text {arom }}-\mathrm{c} / \mathrm{d}$ ), 7.69 (d, J = 8.4 Hz, 2H, $\mathrm{H}_{\text {arom }} \mathrm{a} / \mathrm{b}$ ), 7.28 (s, 2H, $\mathrm{SO}_{2} \mathrm{NH}_{2}$ ), 5.85 (brs, 1H, H-1), 5.28-5.22 (m, 2H, H-3, H-1'), 5.15 (dd, $J=$ 9.9, 3.2 Hz, 1H, H-3'), 4.93 (vt, $J=9.4$ Hz, 1H, H-2), 4.87 (vt, $J=9.8 \mathrm{~Hz}, 1 \mathrm{H}, \mathrm{H}-2$ '), 4.78 (dd, $J=$ 8.0, 1.0 Hz, 1H, H-4'), 4.295 (dd, $J=1.0,11.6$ Hz, 1H, H-6a), 4.26-4.21 (m, 1H, H-5'), 4.08-4.00 (m, 3H, H-6b, H-6'a/b), 3.89-3.80 (m, 2H, H-4, H-5), 2.11, 2.05, 2.02, 2.01, 2.00, 1.99, 1.90 (7 × s, $\left.21 \mathrm{H}, \mathrm{OCOC} H_{3}\right)$, assignments were confirmed by ${ }^{1} \mathrm{H}-{ }^{1} \mathrm{H}$ gCOSY. ${ }^{13} \mathrm{C}$ NMR $\left(125 \mathrm{MHz}\right.$, DMSO- $\left.d_{6}\right)$ $\delta=181.9(\mathrm{C}=\mathrm{S}), 170.2,169.9,169.8,169.5,169.5,169.3,169.0\left(C \mathrm{OCH}_{3}\right), 142.0\left(C_{\text {arom }}-\mathrm{SO}_{2} \mathrm{NH}_{2}\right)$, $139.4\left(\mathrm{C}_{\text {arom }}\right), 126.2\left(\mathrm{CH}_{\text {arom}} \mathrm{a} / \mathrm{b}\right), 122.0\left(\mathrm{CH}_{\text {arom }}-\mathrm{c} / \mathrm{d}\right), 99.7\left(\mathrm{C}-1^{\prime}\right), 80.9(\mathrm{C}-1), 76.0(\mathrm{C}-4), 73.3(\mathrm{C}-$ 3), 73.0 (C-5), 70.6 (C-2), 70.3 (C-3'), 69.7 (C-5'), 68.8 (C-2'), 67.1 (C-4'), 62.2 (C-6), 60.9 (C-6'), 20.6. 20.5, 20.4, 20.3, $20.3\left(7 \times \mathrm{OCOCH}_{3}\right)$, assignments were confirmed by ${ }^{1} \mathrm{H}_{-}{ }^{13} \mathrm{C} \mathrm{HSQC}$. HRMS: Calcd for $\mathrm{C}_{33} \mathrm{H}_{44} \mathrm{~N}_{3} \mathrm{O}_{19} \mathrm{~S}_{2}{ }^{+} 850.2005$, Found 850.2019.

4.1.17. $N$-[4-(Aminosulfonyl)benzyl]- $N^{\prime}-\left(2^{\prime}, 2^{\prime \prime}, 3^{\prime}, 3^{\prime \prime}, 4^{\prime}, 6^{\prime}, 6^{\prime \prime}\right.$-hepta- $O$-acetyl-D-lactosyl)thiourea (22) 
The title compound $\mathbf{2 2}$ was prepared from amine $\mathbf{2}$ and isothiocyanate $\mathbf{8}$ according to general procedure 1 to give a white solid. m.p. $=157-158{ }^{\circ} \mathrm{C} ;{ }^{1} \mathrm{H}$ NMR $\left(500 \mathrm{MHz}, \mathrm{DMSO}-d_{6}\right) \delta=8.31(\mathrm{~s}$, 1H, CHNH), 8.14 (brs, 1H, NH- $\mathrm{CH}_{2}$ ), 7.76 (d, J=8.2 Hz, 2H, $\left.\mathrm{H}_{\text {arom }}-\mathrm{c} / \mathrm{d}\right), 7.40$ (d, J = 7.9 Hz, 2H, $\mathrm{H}_{\text {arom }} \mathrm{a} / \mathrm{b}$ ), 7.29 (s, 2H, $\mathrm{SO}_{2} \mathrm{NH}_{2}$ ), 5.74 (brs, 1H, H-1), 5.23 (d, J=3.5, 1H, H-1'), 5.21-5.12 (m, 2H, H-3, H-3'), 4.88-4.70 (m, 5H, H-2, H-4', H-5', NH-CH $), 4.28$ (dd, J = 1.0, 11.7 Hz, 1H, H-6a), 4.23 (vt, $J=6.6 \mathrm{~Hz}, 1 \mathrm{H}, \mathrm{H}-2^{\prime}$ ), 4.08-4.00 (m, 3H, H-6b, H-6'a/b), 3.83-3.78 (m, 2H, H-4, H-5), 2.10, 2.04, 2.01, 2.00, 1.99, 1.98, $1.90(7 \times \mathrm{s}, 21 \mathrm{H}, \mathrm{OCOCH})$, assignments were confirmed by ${ }^{1} \mathrm{H}-{ }^{1} \mathrm{H}$ gCOSY. ${ }^{13} \mathrm{C}$ NMR $\left(125 \mathrm{MHz}, \mathrm{DMSO}-d_{6}\right) \delta=183.7(\mathrm{C}=\mathrm{S}), 170.3,170.2,169.8,169.8,169.4$, 169.3, $169.0\left(\mathrm{COCH}_{3}\right), 142.7\left(C_{\text {arom }}-\mathrm{SO}_{2} \mathrm{NH}_{2}\right), 139.1\left(\mathrm{C}_{\text {arom }}\right), 127.4\left(\mathrm{CH}_{\text {arom }} \mathrm{a} / \mathrm{b}\right), 125.6\left(\mathrm{CH}_{\text {arom }}{ }^{-}\right.$ c/d), 99.7 (C-1'), 80.3 (C-1), 76.0 (C-4), 73.3 (C-5), 70.8 (C-3), 70.3 (C-2), 69.7 (C-3'), 68.8, 67.1 (C-2', C-5'), 62.2 (C-4'), 60.9 (C-6), 59.7 (C-6'), $46.6\left(\mathrm{NH}-C H_{2}\right), 20.7,20.6,20.4,20.4,20.3,20.3$, $20.2\left(\mathrm{OCOCH}_{3}\right)$, assignments were confirmed by ${ }^{1} \mathrm{H}-{ }^{13} \mathrm{C}$ HSQC. HRMS: Calcd for $\mathrm{C}_{34} \mathrm{H}_{45} \mathrm{~N}_{3} \mathrm{O}_{19} \mathrm{~S}_{2} \mathrm{Na}^{+}$886.1981, Found 886.2006.

\subsubsection{8. $\quad N$-[4-(Aminosulfonyl)phenethyl]- $N^{\prime}-\left(2^{\prime}, 2^{\prime \prime}, 3^{\prime}, 3^{\prime \prime}, 4^{\prime \prime}, 6^{\prime}, 6^{\prime \prime}\right.$-hepta- $O$-acetyl-D-}

\section{lactosyl)thiourea (23)}

The title compound $\mathbf{2 3}$ was prepared from amine $\mathbf{3}$ and isothiocyanate $\mathbf{8}$ according to general procedure 1 to give a white solid. m.p. $=128-130{ }^{\circ} \mathrm{C} ;{ }^{1} \mathrm{H}$ NMR $\left(500 \mathrm{MHz}, \mathrm{DMSO}-d_{6}\right) \delta=7.93$ (brs, 1H, NHCH), 7.80 (brs, $1 \mathrm{H}, \mathrm{NH}-\mathrm{CH}_{2}$ ), 7.75 (d, J = 8.1 Hz, 2H, $\left.\mathrm{H}_{\text {arom }}-\mathrm{c} / \mathrm{d}\right), 7.40$ (d, J = 8.2 Hz, $2 \mathrm{H}, \mathrm{H}_{\text {arom }} \mathrm{a} / \mathrm{b}$ ), 7.27 (s, 2H, $\mathrm{SO}_{2} \mathrm{NH}_{2}$ ), 5.70 (brs, $1 \mathrm{H}, \mathrm{H}-1$ ), 5.23 (d, J=3.4 Hz, 1H, H-4'), 5.21-5.11 (m, 2H, H-3, H-3'), 4.90-4.83 (m, 1H, H-2'), 4.82-4.72 (m, 2H, H-1', H-2), 4.30-4.20 (m, 2H, H-5, H-6a), 4.07-3.99 (m, 4H, H-6b, H-6'a/b), 3.82-3.76 (m, 2H, H-4, H-5'), 3.67 (brs, 2H, CH $\mathrm{H}_{2} \mathrm{H}$ ), 2.89 (brs, $\left.2 \mathrm{H}, \mathrm{CH}_{2}-\mathrm{CH}_{\text {arom }}\right), 2.10,2.06,2.01,2.00,1.98,1.95,1.90\left(7 \times \mathrm{s}, 21 \mathrm{H}, \mathrm{OCOCH}_{3}\right)$ assignments were confirmed by ${ }^{1} \mathrm{H}-{ }^{1} \mathrm{H}$ gCOSY. ${ }^{13} \mathrm{C}$ NMR $\left(125 \mathrm{MHz}, \mathrm{DMSO}-d_{6}\right) \delta=184.0(\mathrm{C}=\mathrm{S})$, 170.6, 170.4, 170.3, 170.0, 169.9, 169.8, 169.5, $\left(C \mathrm{CCH}_{3}\right), 143.8\left(C_{\text {arom }}-\mathrm{SO}_{2} \mathrm{NH}_{2}\right), 142.6\left(\mathrm{C}_{\text {arom }}\right)$,

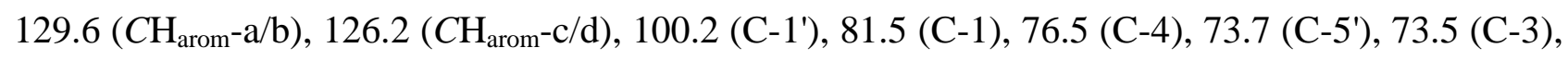
71.2 (C-2), 70.8 (C-3'), 70.2 (C-5), 69.3 (C-2'), 67.6 (C-4'), $62.7(\mathrm{C}-6), 61.4\left(\mathrm{C}^{\prime} 6^{\prime}\right), 45.3\left(\mathrm{CH}_{2} \mathrm{NH}\right)$, $34.1\left(\mathrm{CH}_{2} \mathrm{C}_{\text {arom }}\right), 21.2,21.0,20.9,20.9,20.8,20.8,20.8\left(\mathrm{OCOCH}_{3}\right)$, assignments were confirmed by ${ }^{1} \mathrm{H}-{ }^{13} \mathrm{C}$ HSQC. HRMS: Calcd for $\mathrm{C}_{35} \mathrm{H}_{48} \mathrm{~N}_{3} \mathrm{O}_{19} \mathrm{~S}_{2}{ }^{+}$878.2318, Found 878.2329.

\subsubsection{9. $\quad N$-[4-(Aminosulfonyl)phenylhydrazido]- $N^{\prime}-\left(2^{\prime}, 2^{\prime \prime}, 3^{\prime}, 3^{\prime \prime}, 4^{\prime \prime}, 6^{\prime}, 6^{\prime \prime}\right.$-hepta- $O$-acetyl-D- lactosyl)thiourea (24)}

The title compound $\mathbf{2 4}$ was prepared from amine $\mathbf{4}$ and isothiocyanate $\mathbf{8}$ according to general procedure 1 to give a white solid. m.p. $=159-161{ }^{\circ} \mathrm{C} ;{ }^{1} \mathrm{H}$ NMR $\left(500 \mathrm{MHz}, \mathrm{DMSO}-d_{6}\right) \delta=10.48$ 
(brs, 1H, NH), 9.87 (brs, 1H, NH), 8.43 (s, 1H, CHNH), 8.03 (d, J=8.0 Hz, 2H, Harom-c/d), 7.92 (d, J = 7.2 Hz, 2H, $\mathrm{H}_{\text {arom }}$-a/b), 7.49 (s, 2H, $\mathrm{SO}_{2} \mathrm{NH}_{2}$ ), 5.79 (vt, J = 8.8 Hz, 1H, H-1), 5.26-5.09 (m, 3H, H-3, H-3', H-4'), 4.98 (vt, J = 8.9 Hz, 1H, H-2), 4.85 (vt, J = 8.4 Hz, 1H, H-2'), 4.76 (d, J = 8.0 Hz, 1H, H-1'), 4.28 (dd, J = 1.0, 11.6 Hz, 1H, H-6a), 4.24-4.20 (m, 1H, H-5'), 4.09-3.94 (m, 3H, H6b, H-6'a/b), 3.84-3.80 (m, 1H, H-5), 3.74 (vt, J = 7.9 Hz, 1H, H-4), 2.10, 2.06, 2.00, 1.95, 1.91, $1.90\left(6 \times \mathrm{s}, 21 \mathrm{H}, \mathrm{OCOCH}_{3}\right)$, assignments were confirmed by ${ }^{1} \mathrm{H}-{ }^{1} \mathrm{H}$ gCOSY ${ }^{13} \mathrm{C}$ NMR $(125 \mathrm{MHz}$, DMSO- $\left.d_{6}\right) \delta=181.9(\mathrm{C}=\mathrm{S}), 170.4,170.1,169.7,169.6,169.5,169.3\left(7 \times \mathrm{COCH}_{3}\right), 165.3$ $(\mathrm{NHC}=\mathrm{O}), 146.8\left(C_{\mathrm{arom}}-\mathrm{SO}_{2} \mathrm{NH}_{2}\right), 126.2\left(\mathrm{C}_{\mathrm{arom}}\right), 128.7\left(\mathrm{CH}_{\mathrm{arom}}-\mathrm{a} / \mathrm{b}\right), 125.6\left(\mathrm{CH}_{\mathrm{arom}}-\mathrm{c} / \mathrm{d}\right), 99.7(\mathrm{C}-$ 1'), 82.9 (C-1), 76.0 (C-4), 73.3 (C-5), 73.6 (C-3), 73.2 (C-2), 70.5 (C-3'), 69.9, 69.0 (C-5', C-2'), 67.3 (C-4'), 62.4 (C-6), 61.1 (C-6'), 20.8, 20.6, 20.6, 20.5, 20.5, 20.4 (7× $\left.\mathrm{OCOCH}_{3}\right)$, assignments were confirmed by ${ }^{1} \mathrm{H}-{ }^{13} \mathrm{C}$ HSQC. HRMS: Calcd for $\mathrm{C}_{34} \mathrm{H}_{45} \mathrm{~N}_{4} \mathrm{O}_{20} \mathrm{~S}_{2}{ }^{+}$893.2063, Found 893.2067.

\subsubsection{0. $N$-[4-(Aminosulfonyl)phenyl]- $N^{\prime}$-( $\beta$-D-glucopyranosyl)thiourea (25)}

The title compound $\mathbf{2 5}$ was prepared from compound $\mathbf{9}$ according to general procedure 2 to give a white solid. m.p. $=148-149{ }^{\circ} \mathrm{C}($ decomp$) ;{ }^{1} \mathrm{H}$ NMR $\left(500 \mathrm{MHz}, \mathrm{DMSO}-d_{6}\right) \delta=9.96$ (brs, $\left.1 \mathrm{H}, \mathrm{N} H\right)$, 8.34 (brs, 1H, CHNH), 7.75 (s, 4H, $\mathrm{H}_{\text {arom }}$ ), 7.27 (s, 2H, SO $\mathrm{NH}_{2}$ ), 5.28 (brs, $\left.1 \mathrm{H}, \mathrm{H}-1\right), 5.12$ (d, $J=$ 3.9, 1H, OH-3), 5.03 (d, $J=4.2,1 \mathrm{H}, \mathrm{OH}-2$ ), 4.89 (brs, 1H, OH-4), 4.45 (brs, 1H, OH-6), 3.69-3.61 (m, 1H, H-6a), 3.51-3.44 (m, 1H, H-6b), 3.27-3.21 (m, 1H, H-2) 3.20-3.10 (m, 3H, H-3, H-4, H-5), assignments were confirmed by ${ }^{1} \mathrm{H}-{ }^{1} \mathrm{H}$ gCOSY.${ }^{13} \mathrm{C}$ NMR $\left(125 \mathrm{MHz}, \mathrm{D}_{2} \mathrm{O}\right) \delta=181.9(\mathrm{C}=\mathrm{S}), 142.4$ $\left(C_{\text {arom }}-\mathrm{SO}_{2} \mathrm{NH}_{2}\right), 139.1\left(\mathrm{C}_{\text {arom }}\right), 126.1,122.1\left(C_{\text {arom }}\right), 83.5(\mathrm{C}-1), 78.3(\mathrm{C}-4), 77.5(\mathrm{C}-2), 72.6(\mathrm{C}-$ 3), 69.8 (C-5), 60.7 (C-6), assignments were confirmed by ${ }^{1} \mathrm{H}-{ }^{13} \mathrm{C}$ HSQC. HRMS: Calcd for $\mathrm{C}_{13} \mathrm{H}_{21} \mathrm{~N}_{3} \mathrm{O}_{7} \mathrm{~S}_{2}{ }^{+}$394.0737, Found 394.0746.

\subsubsection{1. $N$-[4-(Aminosulfonyl)benzyl]- $N$ '-( $\beta$-D-glucopyranosyl)thiourea (26)}

The title compound $\mathbf{2 6}$ was prepared from compound $\mathbf{1 0}$ according to general procedure 2 to give a white solid. m.p. $=125-127{ }^{\circ} \mathrm{C} ;{ }^{1} \mathrm{H} \operatorname{NMR}\left(500 \mathrm{MHz}, \mathrm{D}_{2} \mathrm{O}\right) \delta=7.95\left(\mathrm{~d}, J=8.2 \mathrm{~Hz}, 2 \mathrm{H}, \mathrm{H}_{\text {arom }}-\mathrm{c} / \mathrm{d}\right)$, 7.59 (d, $\left.J=8.2 \mathrm{~Hz}, 2 \mathrm{H}, \mathrm{H}_{\mathrm{arom}} \mathrm{a} / \mathrm{b}\right), 5.41$ (brs, $\left.1 \mathrm{H}, \mathrm{H}-1\right), 4.96$ (s, 2H, $\mathrm{SO}_{2} \mathrm{NH}_{2}$ ), 3.95 (dd, $J=1.6$, $12.4 \mathrm{~Hz}, 1 \mathrm{H}, \mathrm{H}-6 \mathrm{a}), 3.80$ (dd, $J=5.3,12.3 \mathrm{~Hz}, 1 \mathrm{H}, \mathrm{H}-6 \mathrm{~b}$ ), 3.67-3.58 (m, 2H, H-2, H-5), 3.53 (vt, $J$ $=9.1,1 \mathrm{H}, \mathrm{H}-3), 3.50(\mathrm{vt}, J=9.5,1 \mathrm{H}, \mathrm{H}-4)$, assignments were confirmed by ${ }^{1} \mathrm{H}-{ }^{1} \mathrm{H}$ gCOSY.${ }^{13} \mathrm{C}$ NMR $\left(125 \mathrm{MHz}, \mathrm{D}_{2} \mathrm{O}\right) \delta=163.4(\mathrm{C}=\mathrm{S}), 140.1\left(C_{\text {arom }}-\mathrm{SO}_{2} \mathrm{NH}_{2}\right), 132.9\left(\mathrm{C}_{\text {arom }}\right), 127.7\left(C \mathrm{H}_{\text {arom }}-\mathrm{a} / \mathrm{b}\right)$, $126.1\left(\mathrm{CH}_{\text {arom}}\right.$-c/d), 83.2 (C-1), 77.1 (C-5), 76.5 (C-2), 72.1, 69.3 (C-3, C-4), 60.6 (C-6), 47.3 (NH$\mathrm{CH}_{2}$ ), assignments were confirmed by ${ }^{1} \mathrm{H}^{-}{ }^{13} \mathrm{C}$ HSQC. HRMS: Calcd for $\mathrm{C}_{14} \mathrm{H}_{22} \mathrm{~N}_{3} \mathrm{O}_{7} \mathrm{~S}_{2}{ }^{+} 408.0894$, Found 408.0899. 


\subsubsection{2. $N$-[4-(Aminosulfonyl)phenethyl]- $N^{\prime}$-(B-D-glucopyranosyl)thiourea (27)}

The title compound $\mathbf{2 7}$ was prepared from compound $\mathbf{1 1}$ according to general procedure 1 to give a white solid. m.p. $=134-136{ }^{\circ} \mathrm{C} ;{ }^{1} \mathrm{H}$ NMR $\left(500 \mathrm{MHz}, \mathrm{D}_{2} \mathrm{O}\right) \delta=7.80\left(\mathrm{~d}, J=7.9 \mathrm{~Hz}, 1 \mathrm{H}, \mathrm{H}_{\text {arom }}-\mathrm{c} / \mathrm{d}\right)$, 7.44 (d, $J=7.9 \mathrm{~Hz}, 1 \mathrm{H}, \mathrm{H}_{\text {arom }} \mathrm{a} / \mathrm{b}$ ), 5.09 (brs, $1 \mathrm{H}, \mathrm{H}-1$ ), 3.87-3.73 (m, 3H, H-3, $\mathrm{CH}_{2} \mathrm{NH}$ ), 3.66 (brs, 1H, H-4), $3.51-3.30$ (m, 4H, H-2, H-5, H-6a/b), 2.98 (s, 2H, $\mathrm{CH}_{2} \mathrm{C}_{\text {arom }}$ ), assignments were confirmed by ${ }^{1} \mathrm{H}-{ }^{1} \mathrm{H}$ gCOSY. ${ }^{13} \mathrm{C}$ NMR $\left(125 \mathrm{MHz}, \mathrm{D}_{2} \mathrm{O}\right) \delta=182.6(\mathrm{C}=\mathrm{S}), 145.0\left(C_{\text {arom }}-\mathrm{SO}_{2} \mathrm{NH}_{2}\right)$, $139.21\left(\mathrm{C}_{\text {arom }}\right), 130.0\left(\mathrm{CH}_{\text {arom }} \mathrm{a} / \mathrm{b}\right), 126.0\left(\mathrm{CH}_{\text {arom }}\right.$-c/d), $83.1(\mathrm{C}-1), 77.1(\mathrm{C}-5), 76.5(\mathrm{C}-3), 71.9(\mathrm{C}-$ 4), 69.2 (C-2), 60.5 (C-6), $45.2\left(\mathrm{NHCH}_{2}\right), 34.2\left(\mathrm{CH}_{2} \mathrm{C}_{\text {arom }}\right)$, assignments were confirmed by ${ }^{1} \mathrm{H}-{ }^{13} \mathrm{C}$ HSQC. HRMS: Calcd for $\mathrm{C}_{15} \mathrm{H}_{24} \mathrm{~N}_{3} \mathrm{O}_{7} \mathrm{~S}_{2}{ }^{+} 422.1050$, Found 422.1048 .

\subsubsection{3. $N$-[4-(Aminosulfonyl)phenylhydrazido]- $N^{\prime}$-( $\beta$ - D-glucopyranosyl)thiourea (28)}

The title compound $\mathbf{2 8}$ was prepared from compound $\mathbf{1 2}$ according to general procedure 2 to give a white solid. m.p. $=182-184{ }^{\circ} \mathrm{C}$ (decomposition); ${ }^{1} \mathrm{H}$ NMR $\left(500 \mathrm{MHz}, \mathrm{D}_{2} \mathrm{O}\right) \delta=8.08-8.16(\mathrm{~m}, 4 \mathrm{H}$, $\mathrm{H}_{\text {arom }}$ ), 5.64 (brs, 1H, H-1), 3.97 (dd, $\left.J=12.4,2.0 \mathrm{~Hz}, 1 \mathrm{H}, \mathrm{H}-6 \mathrm{a}\right), 3.82$ (dd, $J=12.4,5.2 \mathrm{~Hz}, 1 \mathrm{H}, \mathrm{H}-$ 6b), 3.60-3.69 (m, 3H, H-2, H-3, H-5), 3.51 (vt, $J=9.4$ Hz, 1H, H-4), assignments were confirmed by ${ }^{1} \mathrm{H}-{ }^{1} \mathrm{H}$ gCOSY. ${ }^{13} \mathrm{C}$ NMR $\left(125 \mathrm{MHz}, \mathrm{D}_{2} \mathrm{O}\right) \delta=180.4(\mathrm{C}=\mathrm{S}), 163.4(\mathrm{NHC}=\mathrm{O}), 158.9\left(C_{\text {arom }^{-}}\right.$ $\left.\mathrm{SO}_{2} \mathrm{NH}_{2}\right), 143.5\left(\mathrm{C}_{\text {arom}}\right), 126.8,126.7\left(\mathrm{CH}_{\text {arom }}\right), 83.6$ (C-1), 77.4 (C-3), $76.5(\mathrm{C}-2), 72.1$ (C-5), 69.3 (C-4), 60.6 (C-6), assignments were confirmed by ${ }^{1} \mathrm{H}-{ }^{13} \mathrm{C}$ HSQC; HRMS: Calcd for $\mathrm{C}_{14} \mathrm{H}_{21} \mathrm{~N}_{4} \mathrm{O}_{8} \mathrm{~S}_{2}{ }^{+}$ 437.0795, Found 437.0797.

\subsubsection{4. $N$-[4-(Aminosulfonyl)phenyl]- $N^{\prime}$-( $\beta$-D-galactopyranosyl)thiourea (29)}

The title compound 29 was prepared from compound 13 according to general procedure 2 to give a white solid. m.p. $=177-179{ }^{\circ} \mathrm{C}($ decomp$) ;{ }^{1} \mathrm{H}$ NMR $\left(500 \mathrm{MHz}, \mathrm{D}_{2} \mathrm{O}\right) \delta=7.89(\mathrm{~d}, J=8.7 \mathrm{~Hz}, 2 \mathrm{H}$, $\mathrm{H}_{\text {arom }}-\mathrm{c} / \mathrm{d}$ ), 7.56 (d, $J=8.4 \mathrm{~Hz}, 2 \mathrm{H}, \mathrm{H}_{\text {arom-a/b) }} 5.46$ (brs, $\left.1 \mathrm{H}, \mathrm{H}-1\right), 3.99-3.93$ (m, 1H, H-3), 3.78 (dd, J = 6.4, 9.2 Hz, 1H, H-2), 3.74-3.68 (m, 4H, H-4, H-5, H-6a/b), assignments were confirmed by ${ }^{1} \mathrm{H}-{ }^{1} \mathrm{H}$ gCOSY. ${ }^{13} \mathrm{C}$ NMR $\left(125 \mathrm{MHz}, \mathrm{D}_{2} \mathrm{O}\right) \delta=184.7(\mathrm{C}=\mathrm{S}), 136.6\left(C_{\text {arom }}-\mathrm{SO}_{2} \mathrm{NH}_{2}\right), 129.4\left(\mathrm{C}_{\text {arom }}\right)$, $125.1\left(\mathrm{CH}_{\text {arom-a }}{ }^{\mathrm{a}} / \mathrm{b}\right), 124.9\left(\mathrm{CH}_{\text {arom}}{ }^{-\mathrm{c}} / \mathrm{d}\right), 83.1(\mathrm{C}-1), 74.4(\mathrm{C}-3), 71.3(\mathrm{C}-4), 67.4(\mathrm{C}-5), 66.5(\mathrm{C}-2)$, 58.8 (C-6), assignments were confirmed by ${ }^{1} \mathrm{H}_{-}{ }^{13} \mathrm{C}$ HSQC. HRMS: Calcd for $\mathrm{C}_{13} \mathrm{H}_{20} \mathrm{~N}_{3} \mathrm{O}_{7} \mathrm{~S}_{2} \mathrm{Na}^{+}$ 416.0557, Found 416.0570.

\subsubsection{5. $N$-[4-(Aminosulfonyl)benzyl]- $N$ '-( $\beta$-D-galactopyranosyl)thiourea (30)}

The title compound 30 was prepared from compound 14 according to general procedure 2 to give a white solid. m.p. $=144-146{ }^{\circ} \mathrm{C} ;{ }^{1} \mathrm{H}$ NMR $\left(500 \mathrm{MHz}, \mathrm{D}_{2} \mathrm{O}\right) \delta=7.83\left(\mathrm{~d}, J=8.3 \mathrm{~Hz}, 2 \mathrm{H}, \mathrm{H}_{\text {arom }}-\mathrm{c} / \mathrm{d}\right)$, 7.48 (d, $\left.J=8.3 \mathrm{~Hz}, 2 \mathrm{H}, \mathrm{H}_{\mathrm{arom}} \mathrm{-a} / \mathrm{b}\right), 5.24$ (brs, 1H, H-1), 4.84 (s, 2H, NH-CH2), 3.95-3.92 (m, 1H, 
H-3), 3.77-3.71 (m, J = 6.4, 10.5 Hz, 1H, H-4), 3.71-3.64 (m, 4H, H-2, H-5, H-6a/b), assignments were confirmed by ${ }^{1} \mathrm{H}_{-}{ }^{1} \mathrm{H}$ gCOSY. ${ }^{13} \mathrm{C}$ NMR $\left(125 \mathrm{MHz}, \mathrm{DMSO}-d_{6}\right) \delta=179.7(\mathrm{C}=\mathrm{S}), 143.4\left(C_{\mathrm{arom}^{-}}\right.$ $\left.\mathrm{SO}_{2} \mathrm{NH}_{2}\right)\left(\mathrm{C}_{\mathrm{arom}}\right), 128.0\left(\mathrm{CH}_{\text {arom }}-\mathrm{a} / \mathrm{b}\right), 126.0\left(\mathrm{CH}_{\text {arom }}-\mathrm{c} / \mathrm{d}\right), 77.1(\mathrm{C}-1), 76.6(\mathrm{C}-4), 74.5(\mathrm{C}-5), 70.2$ (C-2), 68.5 (C-3), $60.6(\mathrm{C}-6), 47.3\left(\mathrm{NH}-\mathrm{CH}_{2}\right)$, assignments were confirmed by ${ }^{1} \mathrm{H}-{ }^{13} \mathrm{C}$ HSQC. HRMS: Calcd for $\mathrm{C}_{14} \mathrm{H}_{22} \mathrm{~N}_{3} \mathrm{O}_{7} \mathrm{~S}_{2}{ }^{+} 408.0894$, Found 408.0908.

\subsubsection{6. $N$-[4-(Aminosulfonyl)phenethyl]- $N^{\prime}$-( $\beta$-D-galactopyranosyl)thiourea (31)}

The title compound $\mathbf{3 1}$ was prepared from compound $\mathbf{1 5}$ according to general procedure 1 to give a white solid. m.p. $=136-138{ }^{\circ} \mathrm{C} ;{ }^{1} \mathrm{H} \operatorname{NMR}\left(500 \mathrm{MHz}, \mathrm{D}_{2} \mathrm{O}\right) \delta=7.92\left(\mathrm{~d}, J=7.7 \mathrm{~Hz}, 2 \mathrm{H}, \mathrm{H}_{\text {arom }}-\mathrm{c} / \mathrm{d}\right)$, 7.56 (d, $J=7.8 \mathrm{~Hz}, 2 \mathrm{H}, \mathrm{H}_{\text {arom-a/b), }} 5.17$ (brs, 1H, H-1), 4.05-4.00 (m, 1H, H-4), 3.96-3.88 (m, 2H, H-3, H-6a), 3.84-3.70 (m, 5H, H-2, H-5, H-6b, $\mathrm{CH}_{2} \mathrm{NH}$ ), 3.15-3.05 (m, 2H, $\mathrm{CH}_{2} \mathrm{C}_{\text {arom }}$ ), assignments were confirmed by ${ }^{1} \mathrm{H}-{ }^{1} \mathrm{H}$ gCOSY. ${ }^{13} \mathrm{C}$ NMR $\left(125 \mathrm{MHz}, \mathrm{D}_{2} \mathrm{O}\right) \delta=183.4(\mathrm{C}=\mathrm{S}), 143.5\left(C_{\mathrm{arom}^{-}}\right.$ $\left.\mathrm{SO}_{2} \mathrm{NH}_{2}\right), 142.1\left(\mathrm{C}_{\text {arom }}\right), 129.1\left(\mathrm{CH}_{\text {arom }} \mathrm{a} / \mathrm{b}\right), 125.8\left(\mathrm{CH}_{\text {arom }}-\mathrm{c} / \mathrm{d}\right), 84.0(\mathrm{C}-1), 76.2(\mathrm{C}-5), 74.1(\mathrm{C}-2)$, 69.7 (C-4), 68.1 (C-3), 60.2 (C-6), $44.4\left(\mathrm{NH}-\mathrm{CH}_{2}\right), 34.4\left(\mathrm{CH}_{2} \mathrm{C}_{\text {arom}}\right)$, assignments were confirmed by ${ }^{1} \mathrm{H}-{ }^{13} \mathrm{C}$ HSQC. HRMS: Calcd for $\mathrm{C}_{15} \mathrm{H}_{24} \mathrm{~N}_{3} \mathrm{O}_{7} \mathrm{~S}_{2}{ }^{+} 422.1050$, Found 422.1041 .

\subsubsection{7. $N$-[4-(Aminosulfonyl)phenylhydrazido]- $N^{\prime}$-( $\beta$ - D-galactopyranosyl)thiourea (32)}

The title compound $\mathbf{3 2}$ was prepared from compound $\mathbf{1 6}$ according to general procedure 2 to give a white solid. m.p. $=183-184{ }^{\circ} \mathrm{C} ;{ }^{1} \mathrm{H}$ NMR (500 MHz, DMSO- $\left.d_{6}\right) \delta=10.60-10.56(\mathrm{~m}, 1 \mathrm{H}, \mathrm{NH})$, 9.63 (brs, 1H, NH), 8.07 (brs, 1H, NH), 7.91 (d, J = $7.5 \mathrm{~Hz}, 2 \mathrm{H}, \mathrm{H}_{\text {arom }}-\mathrm{c} / \mathrm{d}$ ), 7.49 (brs, $2 \mathrm{H}, \mathrm{H}_{\text {arom }}{ }^{-}$ a/b), 5.30 (brs, 1H, OH), 4.93-4.28 (m, 4H, H-1, $3 \times \mathrm{OH}), 3.74-3.66$ (m, 2H, H-2, H-5), 3.57-3.49 (m, 1H, H-6a), 3.45-3.41 (m, 1H, H-6b), 3.40-3.33 (m, 2H, H-3, H-4) assignments were confirmed by ${ }^{1} \mathrm{H}-{ }^{1} \mathrm{H}$ gCOSY. ${ }^{13} \mathrm{C}$ NMR $\left(125 \mathrm{MHz}, \mathrm{DMSO}-d_{6}\right) \delta=183.5(\mathrm{C}=\mathrm{S}), 165.5(\mathrm{C}=\mathrm{O}), 147.3\left(C_{\text {arom }^{-}}\right.$ $\left.\mathrm{SO}_{2} \mathrm{NH}_{2}\right), 136.1$ ( $\left.\mathrm{C}_{\text {arom }}\right), 128.7\left(\mathrm{CH}_{\text {arom }}-\mathrm{a} / \mathrm{b}\right), 126.1\left(\mathrm{CH}_{\text {arom }}-\mathrm{c} / \mathrm{d}\right), 85.7(\mathrm{C}-1), 74.8,71.4(\mathrm{C}-3, \mathrm{C}-4)$, 69.6 (C-2), 68.3 (C-5), 60.6 (C-6), ) assignments were confirmed by ${ }^{1} \mathrm{H}-{ }^{13} \mathrm{C}$ HSQC. HRMS: Calcd for $\mathrm{C}_{14} \mathrm{H}_{21} \mathrm{~N}_{4} \mathrm{O}_{8} \mathrm{~S}_{2} 437.0795$, Found 437.0816.

\subsubsection{8. $N$-[4-(Aminosulfonyl)phenyl]- $N^{\prime}$-( $\beta$-D-maltosyl)thiourea (33)}

The title compound $\mathbf{3 3}$ was prepared from compound $\mathbf{1 7}$ according to general procedure 2 to give a white solid. m.p. $=170-171{ }^{\circ} \mathrm{C}$ (decomp); ${ }^{1} \mathrm{H}$ NMR $\left(500 \mathrm{MHz}, \mathrm{DMSO}-d_{6}\right) \delta=10.00$ (brs, $1 \mathrm{H}$, $\mathrm{NHCH}), 8.44$ (s, 1H, NH), 7.75 (s, 4H, Harom), 7.27 (s, 2H, $\mathrm{SO}_{2} \mathrm{NH}_{2}$ ), 5.58 (brs, 1H, OH-2), 5.41 (d, $\left.J=6.0 \mathrm{~Hz}, 1 \mathrm{H}, \mathrm{OH}-2^{\prime}\right), 5.34-5.20$ (m, 2H, H-1, OH-4'), 5.05 (d, $\left.J=3.5 \mathrm{~Hz}, 1 \mathrm{H}, \mathrm{H}-1^{\prime}\right), 4.90-4.85$ (m, 2H, OH-3', OH-3), 4.52-4.42 (m, 2H, OH-6, OH-6'), 3.71-3.59 (m, 3H, H-6a, H-6'a/b), 3.563.37 (m, 5H, H-3, H-3', H-5, H-5', H-6b), 3.29-3.21 (m, 3H, H-2, H-2', H-4'), 3.11-3.04 (m, 1H, H- 
4), assignments were confirmed by ${ }^{1} \mathrm{H}-{ }^{1} \mathrm{H}$ gCOSY.${ }^{13} \mathrm{C}$ NMR $\left(125 \mathrm{MHz}\right.$, DMSO- $\left.d_{6}\right) \delta=181.9$ $(\mathrm{C}=\mathrm{S}), 142.3\left(C_{\text {arom }}-\mathrm{SO}_{2} \mathrm{NH}_{2}\right), 139.0\left(\mathrm{C}_{\text {arom }}\right), 126.1,122.2\left(\mathrm{CH}_{\text {arom }}\right), 100.6\left(\mathrm{C}-1^{\prime}\right), 83.5(\mathrm{C}-1), 79.1$ (C-3'), 77.0 (C-5), 76.7 (C-2 or C-2' or C-4'), 73.5 (C-3 or C-5'), 73.3, (C-3 or C-5'), 72.4, 72.1 (C-2 or C-2' or C-4'), 69.9 (C-4), 60.8 (C-6), 60.2 (C-6'), assignments were confirmed by ${ }^{1} \mathrm{H}-{ }^{13} \mathrm{C}$ HSQC. HRMS: Calcd for $\mathrm{C}_{19} \mathrm{H}_{29} \mathrm{~N}_{3} \mathrm{O}_{12} \mathrm{~S}_{2} \mathrm{Na}^{+}$578.1085, Found 578.1105.

\subsubsection{9. $N$-[4-(Aminosulfonyl)benzyl]- $N^{\prime}$-( $\beta$-D-maltosyl)thiourea (34)}

The title compound $\mathbf{3 4}$ was prepared from compound $\mathbf{1 8}$ according to general procedure 2 to give a white solid. m.p. $=184-185^{\circ} \mathrm{C} ;{ }^{1} \mathrm{H} \operatorname{NMR}\left(500 \mathrm{MHz}, \mathrm{D}_{2} \mathrm{O}\right) \delta=7.95\left(\mathrm{~d}, J=7.7 \mathrm{~Hz}, 2 \mathrm{H}, \mathrm{H}_{\text {arom }}-\mathrm{c} / \mathrm{d}\right)$, $7.59\left(\mathrm{~d}, J=8.2 \mathrm{~Hz}, 2 \mathrm{H}, \mathrm{H}_{\text {arom-a/b) }}{ }^{-} 5.48\right.$ (d, $\left.J=3.3 \mathrm{~Hz}, 1 \mathrm{H}, \mathrm{H}-1^{\prime}\right), 5.42$ (brs, 1H, H-1), 4.96 (s, 2H, $\mathrm{CH}_{2} \mathrm{NH}$ ), 3.99-3.88 (m, 3H, H-4, H-6a/b), 3.87-3.71 (m, 6H, H-2, H-3', H-5, H-5', H-6'a/b), 3.64 (dd, $J=3.6,9.3 \mathrm{~Hz}, 1 \mathrm{H}, \mathrm{H}-2^{\prime}$ ), 3.58 (vt, $J=9.2,1 \mathrm{H}, \mathrm{H}-3$ ), 3.50 (vt, $J=9.3,1 \mathrm{H}, \mathrm{H}-4$ '), assignments were confirmed by ${ }^{1} \mathrm{H}-{ }^{1} \mathrm{H}$ gCOSY. ${ }^{13} \mathrm{C} \mathrm{NMR}\left(125 \mathrm{MHz}, \mathrm{D}_{2} \mathrm{O}\right) \delta=(182.3 \mathrm{C}=\mathrm{S}), 143.6\left(C_{\text {arom }}{ }^{-}\right.$ $\left.\mathrm{SO}_{2} \mathrm{NH}_{2}\right), 140.0\left(\mathrm{C}_{\text {arom }}\right), 127.7\left(\mathrm{CH}_{\text {arom }}-\mathrm{a} / \mathrm{b}\right), 126.1\left(\mathrm{CH}_{\text {arom }}\right.$-c/d), 99.6 (C-1'), 83.1 (C-1), $77.0(\mathrm{C}-4)$, 76.4 (C-5), 75.9, 72.9, 72.7 (C-2, C-3', C-5'), 71.9 (C-3), 71.7 (C-2'), 69.4 (C-4'), 60.6 (C-6), 60.5 (C-6'), $47.4\left(\mathrm{NH}-\mathrm{CH}_{2}\right)$, assignments were confirmed by ${ }^{1} \mathrm{H}^{-13} \mathrm{C}$ HSQC; HRMS: Calcd for $\mathrm{C}_{20} \mathrm{H}_{32} \mathrm{~N}_{3} \mathrm{O}_{12} \mathrm{~S}_{2}{ }^{+}$570.1422, Found 570.1401.

\subsubsection{0. $N$-[4-(Aminosulfonyl)phenethyl]- $N^{\prime}$-( $\beta$-D-maltosyl)thiourea (35)}

The title compound 35 was prepared from compound 19 according to general procedure 1 to give a white solid. m.p. $=158-160{ }^{\circ} \mathrm{C} ;{ }^{1} \mathrm{H}$ NMR $\left(500 \mathrm{MHz}, \mathrm{D}_{2} \mathrm{O}\right) \delta=7.81\left(\mathrm{~d}, J=8.2 \mathrm{~Hz}, 2 \mathrm{H}, \mathrm{H}_{\text {arom }}-\mathrm{c} / \mathrm{d}\right)$, $7.46\left(\mathrm{~d}, J=8.1 \mathrm{~Hz}, 2 \mathrm{H}, \mathrm{H}_{\text {arom }} \mathrm{a} / \mathrm{b}\right), 5.35$ (d, J = 3.3 Hz, 1H, H-1'), 5.11 (brs, 1H, H-1), 3.87-5.57 (m, 10H, H-3, H-3', H-5, H-5', H-6a/b, H-6'a/b, NH-CH $H_{2}$, 3.56-3.50 (m, 2H, H-2, H-2' ), 3.40-3.33 (m, 2H, H-4, H-4'), 3.02-2.98 (m, $2 \mathrm{H}, \mathrm{CH}_{2} \mathrm{C}_{\text {arom }}$ ) assignments were confirmed by ${ }^{1} \mathrm{H}-{ }^{1} \mathrm{H}$ gCOSY. ${ }^{13} \mathrm{C}$ NMR $\left(125 \mathrm{MHz}, \mathrm{D}_{2} \mathrm{O}\right) \delta=181.2(\mathrm{C}=\mathrm{S}), 145.0\left(C_{\text {arom }}-\mathrm{SO}_{2} \mathrm{NH}_{2}\right), 139.2\left(\mathrm{C}_{\text {arom }}\right), 129.9\left(C \mathrm{H}_{\text {arom }}-\mathrm{a} / \mathrm{b}\right)$, $126.0\left(\mathrm{CH}_{\text {arom}}\right.$-c/d), 99.6 (C-1'), 83.0 (C-1), 76.9, 76.3, 72.9, 72.7 (C-3, C-3', C-5, C-5'), 75.7, 71.7 (C-2, C-2'), 71.8, 69.3 (C-4, C-4'), 62.5 (C-6), 60.5 (C-6'), $45.2\left(\mathrm{NH}-\mathrm{CH}_{2}\right), 34.2\left(\mathrm{CH}_{2} \mathrm{C}_{\text {arom }}\right)$, assignments were confirmed by ${ }^{1} \mathrm{H}^{-13} \mathrm{C}$ HSQC. HRMS: Calcd for $\mathrm{C}_{21} \mathrm{H}_{33} \mathrm{~N}_{3} \mathrm{O}_{12} \mathrm{~S}_{2} \mathrm{Na}^{+} 606.1398$, Found 606.1425.

\subsubsection{1. $N$-[4-(Aminosulfonyl)phenylhydrazido]- $N^{\prime}$-( $\beta$ - D-maltosyl)thiourea (36)}

The title compound $\mathbf{3 6}$ was prepared from compound $\mathbf{2 0}$ according to general procedure 2 to give a white solid. m.p. $=183-185^{\circ} \mathrm{C} ;{ }^{1} \mathrm{H}$ NMR $\left(500 \mathrm{MHz}, \mathrm{D}_{2} \mathrm{O}\right) \delta=8.05-7.96\left(\mathrm{~m}, 4 \mathrm{H}, \mathrm{H}_{\text {arom }}\right), 5.41(\mathrm{~d}, J$ = $\left.3.9 \mathrm{~Hz}, 1 \mathrm{H}, \mathrm{H}-1^{\prime}\right), 4.91$ (d, $\left.J=9.1 \mathrm{~Hz}, 1 \mathrm{H}, \mathrm{H}-1\right)$, 3.92-3.77 (m, 4H, H-3, H-3', H-6a/b), 3.76-3.66 
(m, 5H, H-4', H-5, H-5', H-6'a/b), 3.58-3.52 (m, 2H, H-2, H-2'), 3.39 (t, $J=9.2,1 \mathrm{H}, \mathrm{H}-4) .{ }^{13} \mathrm{C}$ NMR $\left(125 \mathrm{MHz}, \mathrm{D}_{2} \mathrm{O}\right) \delta=163.4(\mathrm{C}=\mathrm{S}), 159.0(\mathrm{C}=\mathrm{O}), 143.8\left(C_{\text {arom }}-\mathrm{SO}_{2} \mathrm{NH}_{2}\right), 139.2\left(\mathrm{C}_{\text {arom }}\right), 126.9,126.7$ $\left(\mathrm{CH}_{\text {arom }}\right), 99.6$ (C-1'), 83.6 (C-1), 77.0, 76.8 (C-3, C-3'), 76.1, 72.8, 72.6 (C-4', C-5, C-5'), 72.0, 71.8 (C-2, C-2') 69.3 (C-4), 60.5 (C-6), 60.3 (C-6'), assignments were confirmed by ${ }^{1} \mathrm{H}-{ }^{13} \mathrm{C}$ HSQC. HRMS: Calcd for $\mathrm{C}_{20} \mathrm{H}_{30} \mathrm{~N}_{4} \mathrm{O}_{13} \mathrm{~S}_{2} \mathrm{Na}^{+}$621.1143, Found 621.1163.

\subsubsection{2. $N$-[4-(Aminosulfonyl)phenyl]- $N^{\prime}$-( $\beta$-D-lactosyl)thiourea (37)}

The title compound $\mathbf{3 7}$ was prepared from compound $\mathbf{2 1}$ according to general procedure 2 to give a white solid. m.p. $=177-178{ }^{\circ} \mathrm{C}($ decomp$) ;{ }^{1} \mathrm{H}$ NMR $\left(500 \mathrm{MHz}, \mathrm{DMSO}-d_{6}\right) \delta=10.04(\mathrm{~s}, 1 \mathrm{H}$, $\mathrm{NHCH}), 8.50$ (s, 1H, NH), 7.78 (s, 4H, $\left.\mathrm{H}_{\text {arom }}\right), 7.25$ (s, 2H, $\left.\mathrm{SO}_{2} \mathrm{NH}_{2}\right), 5.41-5.20$ (m, 2H, H-1, OH), 5.17-5.00 (m, 1H, OH-), 4.85-4.70 (m, 2H, $2 \times \mathrm{OH})$ 4.69-4.44 (m, 3H, OH-, OH-6, OH-6'), 4.24 (d, $\left.J=7.1 \mathrm{~Hz}, 1 \mathrm{H}, \mathrm{H}-1^{\prime}\right), 3.74-3.60$ (m, 3H, H-4', H-6a/b), 3.58-3.50 (m, 2H, H-3, H-6'a), 3.48 (dd, $J=$ 12.1, 6.1 Hz, 1H, H-6'b), 3.453.21 (m, 6H, H-2, H-2', H-3', H-4, H-5, H-5'), assignments were confirmed by ${ }^{1} \mathrm{H}-{ }^{1} \mathrm{H}$ gCOSY. ${ }^{13} \mathrm{C}$ NMR $\left(125 \mathrm{MHz}, \mathrm{DMSO}-d_{6}\right) \delta=182.0(\mathrm{C}=\mathrm{S}), 142.4\left(C_{\mathrm{arom}^{-}}\right.$ $\left.\mathrm{SO}_{2} \mathrm{NH}_{2}\right), 139.1$ ( $\left.\mathrm{C}_{\text {arom }}\right), 126.1,122.2\left(\mathrm{CH}_{\text {arom }}\right), 103.8\left(\mathrm{C}-1^{\prime}\right), 83.3(\mathrm{C}-1), 80.2\left(\mathrm{C}-3^{\prime}\right), 76.3(\mathrm{C}-3)$, 75.7, 75.6, 73.2 (C-4, C-5, C-5'), 72.3 (C-2), 70.6 (C-2'), 68.2(C-4'), 60.4 (C-6), 60.2 (C-6'), assignments were confirmed by ${ }^{1} \mathrm{H}-{ }^{13} \mathrm{C}$ HSQC. HRMS: Calcd for $\mathrm{C}_{19} \mathrm{H}_{29} \mathrm{~N}_{3} \mathrm{O}_{12} \mathrm{~S}_{2} \mathrm{Na}^{+} 578.1085$, Found 578.1088.

\subsubsection{3. $N$-[4-(Aminosulfonyl)benzyl]- $N^{\prime}$-( $\beta$-D-lactosyl)thiourea (38)}

The title compound $\mathbf{3 8}$ was prepared from compound $\mathbf{2 2}$ according to general procedure 2 to give a white solid. m.p. $=180-182{ }^{\circ} \mathrm{C}$ (decomposition); ${ }^{1} \mathrm{H}$ NMR $\left(500 \mathrm{MHz}, \mathrm{DMSO}-d_{6}\right) \delta=8.13$ (brs, $\left.1 \mathrm{H}, \mathrm{NH}-\mathrm{CH}_{2}\right), 8.07(\mathrm{~d}, J=8.1 \mathrm{~Hz}, 1 \mathrm{H}, \mathrm{NHCH}), 7.77\left(\mathrm{~d}, J=7.9 \mathrm{~Hz}, 2 \mathrm{H}, \mathrm{H}_{\text {arom }}-\mathrm{c} / \mathrm{d}\right), 7.46(\mathrm{~d}, J=8.0$ $\mathrm{Hz}, 2 \mathrm{H}, \mathrm{H}_{\text {arom-a/b) }} 7.28\left(\mathrm{~s}, 2 \mathrm{H}, \mathrm{SO}_{2} \mathrm{NH}_{2}\right), 5.16(\mathrm{~d}, J=5.4 \mathrm{~Hz}, 1 \mathrm{H}, \mathrm{OH}), 5.08(\mathrm{~d}, J=3.8 \mathrm{~Hz}, 1 \mathrm{H}$, $\mathrm{OH}), 4.83-4.81(\mathrm{~m}, 1 \mathrm{H}, \mathrm{OH}), 4.80-4.72(\mathrm{~m}, 3 \mathrm{H}, \mathrm{H}-1,2 \times \mathrm{OH}), 4.63\left(\mathrm{t}, J=5.1 \mathrm{~Hz}, 1 \mathrm{H}, \mathrm{OH}-6{ }^{\prime}\right)$, 4.53 (t, $J=4.7 \mathrm{~Hz}, 1 \mathrm{H}, \mathrm{OH}-6), 4.49$ (d, $J=4.7 \mathrm{~Hz}, 1 \mathrm{H}, \mathrm{OH}-4$ '), 4.23 (d, $\left.J=7.0 \mathrm{~Hz}, 1 \mathrm{H}, \mathrm{H}-1^{\prime}\right), 3.70$ 3.61 (m, 2H, H-4', H-6a/b), 3.57- 3.43 (m, 3H, H-3, H-6'a/b), 3.40-3.25 (m, 8H, H-2, H-2'. H-3', H4, H-5, H-5', NH-CH ), assignments were confirmed by ${ }^{1} \mathrm{H}-{ }^{1} \mathrm{H}$ gCOSY. ${ }^{13} \mathrm{C} \mathrm{NMR}(125 \mathrm{MHz}$, DMSO- $\left.d_{6}\right) \delta=184.3(\mathrm{C}=\mathrm{S}), 143.3\left(C_{\text {arom }}-\mathrm{SO}_{2} \mathrm{NH}_{2}\right), 142.6\left(\mathrm{C}_{\text {arom }}\right), 127.5\left(C_{\text {arom }} \mathrm{a} / \mathrm{b}\right), 125.6$ $\left(\mathrm{CH}_{\text {arom}}{ }^{-\mathrm{c}} \mathrm{d}\right), 103.8\left(\mathrm{C}-1^{\prime}\right), 82.3$ (C-1), 80.3 (C-3'), 75.6 (C-3), 75.5, 73.2, 73.1, 70.6, 70.5 (C-2, C2', C-4, C-5, C-5'), 68.1 (C-4'), 60.4 (C-6), 60.2 (C-6'), $46.7\left(\mathrm{NH}^{\prime} \mathrm{CH}_{2}\right)$, assignments were confirmed by ${ }^{1} \mathrm{H}-{ }^{13} \mathrm{C}$ HSQC. HRMS: Calcd for $\mathrm{C}_{20} \mathrm{H}_{32} \mathrm{~N}_{3} \mathrm{O}_{12} \mathrm{~S}_{2}{ }^{+} 570.1422$, Found 570.1447. 


\subsubsection{4. $N$-[4-(Aminosulfonyl)phenethyl]- $N^{\prime}-(\beta$-D-lactosyl)thiourea (39)}

The title compound $\mathbf{3 9}$ was prepared from compound $\mathbf{2 3}$ according to general procedure 1 to give a white solid. m.p. $=165-167{ }^{\circ} \mathrm{C} ;{ }^{1} \mathrm{H}$ NMR $\left(500 \mathrm{MHz}, \mathrm{D}_{2} \mathrm{O}\right) \delta=7.81\left(\mathrm{~d}, J=8.1 \mathrm{~Hz}, 1 \mathrm{H}, \mathrm{H}_{\text {arom }}-\mathrm{c} / \mathrm{d}\right)$, 7.45 (d, $J=8.1 \mathrm{~Hz}, 1 \mathrm{H}, \mathrm{H}_{\text {arom }}$-a/b), 5.17 (brs, 1H, H-1), 4.41 (d, J= $7.7 \mathrm{~Hz}, 1 \mathrm{H}, \mathrm{H}-1$ '), 3.91-3.35 (m, 14H, H-2, H-2', H-3, H-3', H-4, H-4', H-5, H-5', H-6a/b, H-6'a/b, NH-CH ${ }_{2}$ ), 2.99 (s, 2H, $\mathrm{CH}_{2} \mathrm{C}_{\text {arom}}$ ), assignments were confirmed by ${ }^{1} \mathrm{H}-{ }^{1} \mathrm{H}$ gCOSY. ${ }^{13} \mathrm{C}$ NMR $\left(125 \mathrm{MHz}, \mathrm{D}_{2} \mathrm{O}\right) \delta=182.5(\mathrm{C}=\mathrm{S}), 144.9$ $\left(C_{\text {arom }}-\mathrm{SO}_{2} \mathrm{NH}_{2}\right), 139.2\left(\mathrm{C}_{\text {arom }}\right), 129.9\left(\mathrm{CH}_{\text {arom}}-\mathrm{a} / \mathrm{b}\right), 126.0\left(\mathrm{CH}_{\text {arom }}-\mathrm{c} / \mathrm{d}\right), 102.9\left(\mathrm{C}-1^{\prime}\right), 83.0(\mathrm{C}-1)$, 77.8, 75.9, 75.4, 75.1 72.6, 71.6, 71.0, 68.6 (C-2, C-2', C-3, C-3', C-4, C-4' C-5, C-5'), 61.0, 59.9 (C-6, C-6'), $45.2\left(\mathrm{NH}-\mathrm{CH}_{2}\right), 34.2\left(\mathrm{CH}_{2} \mathrm{C}_{\text {arom }}\right)$, assignments were confirmed by ${ }^{1} \mathrm{H}-{ }^{13} \mathrm{C}$ HSQC. HRMS: Calcd for $\mathrm{C}_{21} \mathrm{H}_{33} \mathrm{~N}_{3} \mathrm{O}_{12} \mathrm{~S}_{2} \mathrm{Na}^{+}$606.1398, Found 606.1411.

\subsubsection{5. $N$-[4-(Aminosulfonyl)phenylhydrazido]- $N$ '-( $\beta$-D-lactosyl)thiourea (40)}

The title compound $\mathbf{4 0}$ was prepared from compound $\mathbf{2 4}$ according to general procedure 2 to give a white solid. m.p. $=189-191{ }^{\circ} \mathrm{C}$ (decomposition); ${ }^{1} \mathrm{H}$ NMR $\left(500 \mathrm{MHz}, \mathrm{DMSO}-d_{6}\right) \delta=9.66(\mathrm{~s}, 1 \mathrm{H}$, $\mathrm{NH}), 8.08$ (d, $J=7.6 \mathrm{~Hz}, 2 \mathrm{H}, \mathrm{H}_{\text {arom }}-\mathrm{c} / \mathrm{d}$ ), 7.81 (brs, $2 \mathrm{H}, \mathrm{H}_{\text {arom}}-\mathrm{a} / \mathrm{b}$ ), 7.39 (brs, $2 \mathrm{H}, \mathrm{SO}_{2} \mathrm{NH}_{2}$ ), 5.37 (brs, 1H, H-1), 5.09 (d, J = 4.0 Hz, 1H, OH-2'), 4.97 (brs, 1H, OH-2), 4.75 (d, J=4.7 Hz, 1H, OH), 4.70 (brs, 1H, OH), 4.64 (t, $J=4.8 \mathrm{~Hz}, 1 \mathrm{H}, \mathrm{OH}-6$ '), 4.56 (t, $J=6.0 \mathrm{~Hz}, 1 \mathrm{H}, \mathrm{OH}-6), 4.48$ (d, $J=4.4$ Hz, 1H, OH), 4.24 (d, J = 7.1 Hz, 1H, H-1'), 3.70-3.65 (m, 2H, H-6a/b), 3.63 (s, 1H, H-3'), 3.573.50 (m, 2H, H-6'a/b), 3.49-3.45 (m, 1H, H-5'), 3.41 (s, 2H, H-2, H-3), 3.38-3.27 (m, 4H, H-2', H-5, $\mathrm{H}-4$ ', H-4), assignments were confirmed by ${ }^{1} \mathrm{H}-{ }^{1} \mathrm{H}$ gCOSY.${ }^{13} \mathrm{C}$ NMR (125 MHz, DMSO- $\left.d_{6}\right) \delta=$ $175.3(\mathrm{C}=\mathrm{S}), 140.6\left(C_{\text {arom }}-\mathrm{SO}_{2} \mathrm{NH}_{2}\right), 136.3\left(\mathrm{C}_{\text {arom }}\right), 158.5(\mathrm{C}=\mathrm{O}), 128.4\left(C_{\mathrm{arom}^{-}} \mathrm{a} / \mathrm{b}\right), 125.5\left(C \mathrm{H}_{\text {arom }}{ }^{-}\right.$ c/d), 104.3 (C-1'), 87.2 (C-1), 81.0, 76.8 (C-2, C-3), 76.3 (C-2', C-4, C-4' or C-5), 76.0 (C-5'), 73.7, 72.4, 71.1 (C-2', C-4, C-4' or C-5), 68.7 (C-3'), 60.9 (C-6), 60.8 (C-6'), assignments were confirmed by ${ }^{1} \mathrm{H}-{ }^{13} \mathrm{C}$ HSQC.

\section{Carbonic anhydrase inhibition assay}

An SX.18MV-R Applied Photophysics stopped-flow instrument has been used for assaying the CA I, II, IX, XII and XIV $\mathrm{CO}_{2}$ hydration activity. ${ }^{46}$ Phenol red (at a concentration of $0.2 \mathrm{mM}$ ) has been used as indicator, working at the absorbance maximum of $557 \mathrm{~nm}$, with $10 \mathrm{mM}$ Hepes (pH 7.5) as buffer, $0.1 \mathrm{M} \mathrm{NaClO}_{4}$ (for maintaining constant the ionic strength - this anion is not inhibitory), following the CA-catalyzed $\mathrm{CO}_{2}$ hydration reaction for a period of $10-100$ s. Saturated $\mathrm{CO}_{2}$ solutions in water at $20^{\circ} \mathrm{C}$ were used as substrate. Stock solutions of inhibitors were prepared at a concentration of $10-50 \mathrm{mM}$ (in the assay buffer) and dilutions up to $1 \mathrm{nM}$ were done with the assay buffer mentioned above. Inhibitor and enzyme solutions were preincubated together for 15 
min at room temperature prior to assay, in order to allow for the formation of the E-I complex. The inhibition constants were obtained by non-linear least-squares methods using PRISM 3. The curvefitting algorithm allowed us to obtain the $\mathrm{IC}_{50}$ values, working at the lowest concentration of substrate of $1.7 \mathrm{mM}$ ), from which $K_{\mathrm{i}}$ values were calculated by using the Cheng-Prusoff equation. The catalytic activity (in the absence of inhibitors) of these enzymes was calculated from Lineweaver-Burk plots and represents the mean from at least three different determinations. Enzyme concentrations were $10.3 \mathrm{nM}$ for CA I and CA II, $12 \mathrm{nM}$ for CA IX, $15 \mathrm{nM}$ for CA XII and $13 \mathrm{nM}$ for CA XIV. Enzymes used here were recombinant ones. 


\section{Acknowledgement}

This work was financed by the Australian Research Council (Grant numbers DP0877554, DP110100071) to S.-A.P. and an EU grant of the $6^{\text {th }}$ framework program (EUROXY project) to C.T.S.

Supporting Information Available: ${ }^{1} \mathrm{H}$ NMR spectra for compounds 9-40.

\section{References}

1. Krishnamurthy, V. M.; Kaufman, G. K.; Urbach, A. R.; Gitlin, I.; Gudiksen, K. L.; Weibel, D. B.; Whitesides, G. M. Chem. Rev. 2008, 108, 946.

2. Supuran, C. T. Nat. Rev. Drug Discovery 2008, 7, 168.

3. Poulsen, S.-A. Expert Opin. Ther. Patents 2010, 20, 795.

4. Wykoff, C. C.; Beasley, N. J.; Watson, P. H.; Turner, K. J.; Pastorek, J.; Sibtain, A.; Wilson, G. D.; Turley, H.; Talks, K. L.; Maxwell, P. H.; Pugh, C. W.; Ratcliffe, P. J.; Harris, A. L. Cancer Res. 2000, 60, 7075.

5. $\quad$ Potter, C. P. S.; Harris, A. L. Br. J. Cancer 2003, 89, 2.

6. $\quad$ Chiche, J.; Ilc, K.; Laferriere, J.; Trottier, E.; Dayan, F.; Mazure, N. M.; Brahimi-Horn, M. C.; Pouyssegur, J. Cancer Res. 2009, 69, 358.

7. Morris, J. C.; Chiche, J.; Grellier, C.; Lopez, M.; Bornaghi, L. F.; Maresca, A.; Supuran, C. T.; Pouyssegur, J.; Poulsen, S.-A. J. Med. Chem. 2011, 54, 6905.

8. $\quad$ Neri, D.; Supuran, C. T. Nat. Rev. Drug Discovery 2011, 10, 767.

9. Oosterwijk, E.; Bander, N. H.; Divgi, C. R.; Welt, S.; Wakka, J. C.; Finn, R. D.; Carswell, E. A.; Larson, S. M.; Warnaar, S. O.; Fleuren, G. J. J. Clin. Oncol. 1993, 11, 738.

10. Grabmaier, K.; Vissers, J. L.; De Weijert, M. C.; Oosterwijk-Wakkai, J.; van Bokhoven, A.; Brakenhoff, R. H.; Noessners, E.; Mulders, P. A.; Merkx, G.; Figdor, C. G.; Adema, G. J.; Oosterwijk, E. Int. J. Cancer 2000, 85, 865.

11. Hilvo, M.; Supuran, C. T.; Parkkila, S. Curr. Top. Med. Chem. 2007, 7, 893.

12. Ogilvie, J. M.; Ohlemiller, K. K.; Shah, G. N.; Ulmasov, B.; Becker, T. A.; Waheed, A.; Hennig, A. K.; Lukasiewicz, P. D.; Sly, W. S. Proc. Nat. Acad. Sci. U.S.A. 2007, 104, 8514.

13. Wilkinson, B. L.; Bornaghi, L. F.; Houston, T. A.; Innocenti, A.; Vullo, D.; Supuran, C. T.; Poulsen, S.-A. Bioorg. Med. Chem. Lett. 2007, 17, 987.

14. Nishimori, I.; Vullo, D.; Innocenti, A.; Scozzafava, A.; Mastrolorenzoc, A.; Supuran, C. T. Bioorg. Med. Chem. Lett. 2005, 15, 3828.

15. Brzozowski, Z.; Slawinski, J.; Saczewski, F.; Innocenti, A.; Supuran, C. T. Eur. J. Med. Chem. 2010, 45, 2396.

16. Scozzafava, A.; Menabuoni, L.; Mincione, F.; Briganti, F.; Mincione, G.; Supuran, C. T. J. Med. Chem. 1999, 42, 2641.

17. Winum, J.-Y.; Poulsen, S.-A.; Supuran, C. T. Med. Res. Rev. 2009, 29, 419.

18. Lopez, M.; Bornaghi, L. F.; Innocenti, A.; Vullo, D.; Charman, S. A.; Supuran, C. T.; Poulsen, S.-A. J. Med. Chem. 2010, 53, 2913.

19. Wilkinson, B. L.; Bornaghi, L. F.; Houston, T. A.; Innocenti, A.; Supuran, C. T.; Poulsen, S.-A. J. Med. Chem. 2006, 49, 6539.

20. Singer, M.; Lopez, M.; Bornaghi, L. F.; Innocenti, A.; Vullo, D.; Supuran, C. T.; Poulsen, S.-A. Bioorg. Med. Chem. Lett. 2009, 19, 2273.

21. Salmon, A. J.; Williams, M. L.; Maresca, A.; Supuran, C. T.; Poulsen, S.-A. Bioorg. Med. Chem. Lett. 2011, 21, 6058. 
22. Wilkinson, B. L.; Bornaghi, L. F.; Houston, T. A.; Innocenti, A.; Vullo, D.; Supuran, C. T.; Poulsen, S.-A. J. Med. Chem. 2007, 50, 1651.

23. Wilkinson, B. L.; Innocenti, A.; Vullo, D.; Supuran, C. T.; Poulsen, S.-A. J. Med. Chem. 2008, 51, 1945.

24. Alterio, V.; Vitale, R. M.; Monti, S. M.; Pedone, C.; Scozzafava, A.; Cecchi, A.; De, S. G.; Supuran, C. T. J. Am. Chem. Soc. 2006, 128, 8329.

25. Casini, A.; Scozzafava, A.; Mincione, F.; Menabuoni, L.; Ilies, M. A.; Supuran, C. T. J. Med. Chem. 2000, 43, 4884.

26. Casini, A.; Scozzafava, A.; Mincione, F.; Menabuoni, L.; Supuran, C. T. J. Enzyme Inhib. Med. Chem. 2002, 17, 333.

27. Cecchi, A.; Ciani, L.; Winum, J.-Y.; Montero, J.-L.; Scozzafava, A.; Ristori, S.; Supuran, C. T. Bioorg. Med. Chem. Lett. 2008, 18, 3475.

28. Di Fiore, A.; De Simone, G.; Menchise, V.; Pedone, C.; Casini, A.; Scozzafava, A.; Supuran, C. T. Bioorg. Med. Chem. Lett. 2005, 15, 1937.

29. Innocenti, A.; Casini, A.; Alcaro, M. C.; Papini, A. M.; Scozzafava, A.; Supuran, C. T. J. Med. Chem. 2004, 47, 5224.

30. Lu, G.; Hillier, S. M.; Maresca, K. P.; Zimmerman, C. N.; Wang, J.; Shay, C.; Marquis, J. C.; Eckelman, W. C.; Joyal, J. L.; Babich, J. W. Small molecule carbonic anhydrase IX inhibitors with Re/Tc for targeted molecular imaging of cancer, 2009;

31. Puccetti, L.; Fasolis, G.; Cecchi, A.; Winum, J.-Y.; Gamberi, A.; Montero, J.-L.; Scozzafava, A.; Supuran, C. T. Bioorg. Med. Chem. Lett. 2005, 15, 2359.

32. Rami, M.; Maresca, A.; Smaine, F.-Z.; Montero, J.-L.; Scozzafava, A.; Winum, J.-Y.; Supuran, C. T. Bioorg. Med. Chem. Lett. 2011, 21, 2975.

33. Scozzafava, A.; Supuran, C. T. J. Enzyme Inhib. 1998, 13, 103.

34. Smith-Jones, P. M.; Zhang, H.; Carlin, S. D. WO2010147666A1; 2010, 109pp.

35. Supuran, C. T.; Scozzafava, A.; Jurca, B. C.; Ilies, M. A. Eur. J. Med. Chem. 1998, 33, 83.

36. Winum, J.-Y.; Dogne, J.-M.; Casini, A.; de Leval, X.; Montero, J.-L.; Scozzafava, A.; Vullo,

D.; Innocenti, A.; Supuran, C. T. J. Med. Chem. 2005, 48, 2121.

37. Poulsen, S.-A. J. Am. Soc. Mass Spectrom. 2006, 17, 1074.

38. Camarasa, M. J.; Fernández-Resa, P.; García-López, M. T.; De Las Heras, F. G.; MéndezCastrillón, P. P.; Felix, A. S. Synthesis 1984, 6, 509.

39. Kühne, M.; Györgydeák, Z.; Lindhorst, T. K. Synthesis 2006, 6, 949.

40. Zemplén, G. Ber. Deutsch. Chem. Ges. 1926, 59, 1254.

41. Vullo, D.; Innocenti, A.; Nishimori, I.; Pastorek, J.; Scozzafava, A.; Pastoreková, S.; Supuran, C. T. Bioorg. Med. Chem. Lett. 2005, 15, 963.

42. Vullo, D.; Franchi, M.; Gallori, E.; Pastorek, J.; Scozzafava, A.; Pastorekova, S.; Supuran, C. T. Bioorg. Med. Chem. Lett. 2003, 13, 1005.

43. Kerns, E. H.; Di, L. Drug-like Properties: Concepts, Structure Design and Methods: from ADME to Toxicity Optimization; London: Academic Press, 2008.

44. Lavis, L. D. ACS Chem. Biol. 2008, 3, 203.

45. Di, L.; Kerns, E. H.; Hong, Y.; Chen, H. Int. J. Pharm. 2005, 297, 110.

46. Khalifah, R. G. J. Biol. Chem. 1971, 246, 2561. 